\title{
MÍDIA, MONOPÓLIO E DEMOCRACIA: UM ESTUDO SOBRE A MONOPOLIZAÇÃO DA MÍDIA NO BRASIL E PORQUE ISSO PODE SER UMA AMEAÇA À DEMOCRACIA
}

\author{
MEDIA, MONOPOLY AND DEMOCRACY: A STUDY ON THE MONOPOLIZATION OF THE \\ MEDIA IN BRAZIL AND WHY IT CAN BE A THREAT TO DEMOCRACY
}

\section{Jordana Siteneski do Amaral ${ }^{1}$ \\ Deborah da Silva Machado²}

\begin{abstract}
SUMÁRIO: Introdução; 1 Panorama da mídia brasileira - a formação do oligopólio e o monopólio da informação; 1.1 Esferas públicas midiatizadas; 2 A democracia deliberativa de Habermas e a importância do discurso; 2.1 Liberdade de imprensa e liberdade de expressão; 2.3 Regulamentação ou censura?; Considerações Finais; Referência das fontes citadas.
\end{abstract}

\section{RESUMO}

Esta pesquisa trata sobre a comunicação no Brasil e a sua estruturação em forma de monopólios regionais, que foram construídos ao longo da história tendo base e origem política e hereditária. Esses monopólios são resultantes de uma tendência global de concentração das indústrias de mídia, e a adoção de uma política neoliberalista que preza pela não intervenção estatal e pela desregulamentação do setor. Outros países investiram em regulamentação dos meios de comunicação de massa, mas no Brasil observa-se uma grande relutância em debater o tema, onde qualquer proposta de regulamentação é chamada de censura. O problema de pesquisa busca responder se a regulação é suficiente para assegurar a liberdade de expressão e o aperfeiçoamento da democracia. A metodologia de trabalho consiste em uma revisão de literatura, além de uma pesquisa feita em bancos de dados, relatórios e processos administrativos. 0 método de abordagem será o hipotético-dedutivo. As hipóteses levantadas pretendem dizer se a regulamentação dos meios de comunicação configura, ou não censura, ou se trata de um mecanismo de aperfeiçoamento da democracia, ao assegurar a liberdade de expressão. Considera-se que a comunicação desempenha um papel fundamental na democracia, partindo de concepção fundada na participação e na soberania popular, e que sua regulação não é censura, uma vez que a comunicação constitui uma importante ferramenta de accountability e de participação deliberativa, e por fim, há que se falar na democratização do acesso aos meios de comunicação de massa.

Palavras-chave: Monopólio; Mídia; Regulamentação; Liberdade de expressão.

\footnotetext{
${ }^{1}$ Mestranda do PPG/DIREITO da Faculdade Meridional (IMED), com bolsa Taxa CAPES/PROSUP. Graduada em Direito pela IMED. Graduada em Jornalismo pela Universidade de Passo Fundo. E-mail: jo.siteneski@hotmail.com; Lattes: http://lattes.cnpq.br/5581775588287895

2 Mestre em Direito pela Mestre em Direito Universidade Regional Integrada do Alto Uruguai e das Missões, URICampus de Santo Ângelo/RS. Graduada em DIREITO na URI-Campus de Erechim/RS. Graduada em ARQUITETURA E URBANISMO pela Uni-Ritter, Porto Alegre/RS. Professora no curso de Arquitetura e Urbanismo na Universidade Federal Fronteira Sul - UFFS, Campus Erechim/RS. E-mail: deborah55machado@gmail.com Lattes: http://lattes.cnpq.br/7733544211444326
} 
AMARAL, Jordana Siteneski do; MACHADO, Deborah da Silva. Mídia, monopólio e democracia: um estudo sobre a monopolização da mídia no Brasil e porque isso pode ser uma ameaça à democracia. Revista Eletrônica Direito e Política, Programa de Pós-Graduação Stricto Sensu em Ciência Jurídica da UNIVALI, Itajaí, v.13, n.2, $2^{\circ}$ quadrimestre de 2018. Disponível em: www.univali.br/direitoepolitica - ISSN 1980-7791

\begin{abstract}
This research deals with communication in Brazil and its structuring in the form of regional monopolies, which were built throughout history having a political and hereditary origin and origin. These monopolies are the result of a global trend of concentration of the media industries, and the adoption of a neoliberalist policy that values non-intervention by the state and deregulation of the sector. Other countries have invested in regulation of the mass media, but in Brazil there is a great reluctance to debate the issue, where any proposal for regulation is called censorship. The research problem seeks to answer whether regulation is sufficient to ensure freedom of expression and the perfection of democracy. The work methodology consists of a literature review, as well as a research done in databases, reports and administrative processes. The method of approach will be the hypothetical-deductive. The hypotheses raised are intended to say whether the regulation of the media constitutes, or not censorship, or is a mechanism for improving democracy, while ensuring freedom of expression. It is considered that communication plays a fundamental role in democracy, starting from a conception based on participation and popular sovereignty, and that its regulation is not censorship, since communication is an important tool of accountability and deliberative participation, and Finally, we must speak about the democratization of access to the mass media.
\end{abstract}

Keywords: Monopoly; Media; Regulation; Freedom of expression.

\title{
INTRODUÇÃO
}

A Constituição Federal de 1988, em seu artigo 220, §50 estabelece que "Os meios de comunicação social não podem, direta ou indiretamente ser objeto de monopólio ou oligopólio.". Entretanto, verifica-se que existe um abismo entre aquilo que estabelece a CF e o que acontece na prática. De acordo com autores e dados coletados para a realização desta pesquisa, as evidências mostram que no caso pátrio o cenário comunicacional é dominado por monopólios regionais, que repercutem uma única visão, um único discurso, impedindo as vozes dissonantes. Esse monopólio ${ }^{3}$ de produção e disseminação de uma só voz, se efetiva através de grandes e poucos conglomerados midiáticos ${ }^{4}$ ao acumularem a propriedade de veículos impressos, concessões de

\footnotetext{
${ }^{3}$ Do ponto de vista do direito econômico, o monopólio ocorre quando um mercado é dominado por apenas um agente econômico, e oligopólio quando essa dominação é exercida por um número reduzido de agentes econômicos. Considerando que não existe um único grupo que domine o mercado, e sim um número reduzido, isso pode levar a conclusão de que na mídia brasileira, existe de fato, um oligopólio configurado. Para avaliar se um mercado é efetivamente oligopolizado ou monopolizado é preciso analisar cada situação de forma individual. Isto porque, analisando-se de perto, pode ser observada a existência de uma situação de alta competitividade, apesar da oligopolização. Da mesma forma, o inverso pode ocorrer: situações em que os poucos agentes restringem ao máximo a concorrência, ao ponto de que esse oligopólio vire de fato, um monopólio. BAGNOLI, Vicente. Introdução ao Direito da Concorrência: Brasil, Mercosul, Globalização, ALCA. São Paulo, Editora Singular, 2005, p.145.

4 Poder-se-ia aqui dizer que no Brasil tem-se um oligopólio nos meios de comunicação, o que é verdade. No entanto, como conceituado anteriormente, o monopólio diz respeito ao discurso, e não à concentração em uma única empresa a dominar o mercado de um determinado produto. Venício A. de Lima é um dos pesquisadores que mais se debruçou sobre a questão das diferenças entre monopólio e oligopólio, bem como sobre em qual destes termos o caso pátrio se encaixaria. Explorando os referidos conceitos no direito econômico. Um exemplo trazido foi o que em 2010 o CADE - Conselho Administrativo de Defesa Econômica julgou, com base no parecer da Secretaria de Direito Econômico - SDE, que a Rede Globo de Televisão exerceu "posição dominante" no mercado, e se viu na obrigação de assinar Termo de Compromisso de Cessação, e cessar práticas que, se presentes
} 
AMARAL, Jordana Siteneski do; MACHADO, Deborah da Silva. Mídia, monopólio e democracia: um estudo sobre a monopolização da mídia no Brasil e porque isso pode ser uma ameaça à democracia. Revista Eletrônica Direito e Política, Programa de Pós-Graduação Stricto Sensu em Ciência Jurídica da UNIVALI, Itajaí, v.13, n.2, 20 quadrimestre de 2018. Disponível em: www.univali.br/direitoepolitica - ISSN 1980-7791

televisão aberta e radiodifusão, portais online, provedores de internet e telefonia e serviços de televisão por assinatura (oligopólio).

O tema é relevante tendo em vista os debates que surgiram ao final do primeiro milênio e, especialmente, na primeira década do século XXI. Tanto é assim, que países - como a vizinha Argentina -, que não tinham qualquer legislação de regulação de mídias, travassem esse debate e aprovassem leis nesse sentido, ainda que sob forte pressão em contrário do próprio setor. A pretensão é que esse trabalho contribua para o debate sobre a democratização dos meios de comunicação no Brasil, por meio de leis e regulamentos, eis que, ao se analisar a realidade da concentração de propriedade (oligopólio), inclusive cruzada, nas mãos de poucos proprietários, oportuniza a monopolização do discurso e a dominação política e ideológica, indo de encontro a preceitos fundamentais da democracia, em especial, o direito constitucional da liberdade de expressão ${ }^{5}$. Justifica-se o tema, também por discutir o papel regulatório do Estado no que diz respeito à legislação que trata da regulação das mídias, e nesse sentido, contribuir com o debate junto à comunidade acadêmica.

Outro fato que reitera a necessidade de pesquisar-se o tema-, é que alguns países (como os EUA, Reino Unido, Equador e Argentina, por exemplo) possuem legislações que regulamentam as mídias com a finalidade de evitar justamente a monopolização do discurso e evitar, dentro do possível, a formação de conglomerados midiáticos, verdadeiros oligopólios, na medida em que reconhecem os efeitos colaterais de uma

determinadas condições previstas na lei, poderiam ensejar infração à ordem econômica. Essa providência leva Lima a concluir que a Rede Globo exerce posição dominante, e sugere que pode se tratar como monopólio, "em razão da fatia de mercado controlada pela empresa e pela sua capacidade de alteração unilateral das regras.". Lima conclui que o caso brasileiro possui consequências fáticas de um monopólio e não oligopólio. Ver: LIMA, Venício A. de; RABELO, Bráulio Santos. Monopólio ou Oligopólio? Contribuição ao debate. In: LIMA, Venício A de. Cultura do Silêncio e democracia no Brasil: ensaios em defesa da liberdade de expressão Brasília: Unb Editora, 2015, p.276. (nota das autoras).

${ }^{5}$ SARLET, Ingo Wolfgang. Liberdade de expressão e biografias não autorizadas - notas sobre a ADI4.815. CONJUR. 19/6/2015. : "Com efeito, apenas para ilustrar tal assertiva mediante a indicação dos principais dispositivos constitucionais sobre o tema, já no artigo $5^{\circ}$, inciso IV, foi solenemente enunciado que "é livre a manifestação do pensamento, sendo vedado o anonimato"; Tal dispositivo, que, é possível arriscar, faz às vezes, no caso brasileiro, de uma espécie de cláusula geral, foi complementado e guarda relação direta com uma série de outros dispositivos da constituição, os quais, no seu conjunto, formam o arcabouço jurídico-constitucional que reconhece e protege a liberdade de expressão nas suas diversas manifestações. Assim, apenas para citar os mais relevantes, no artigo 50 , inciso $V$, "é assegurado o direito de resposta, proporcional ao agravo, além da indenização por dano material, moral ou à imagem"; No inciso VI do mesmo artigo, consta que "é inviolável a liberdade de consciência e de crença, sendo assegurado o livre exercício dos cultos religiosos e garantida, na forma da lei, a proteção aos locais de culto e suas liturgias". Além disso, de acordo com o disposto no artigo 50, IX, "é livre a expressão da atividade intelectual, artística, científica e de comunicação, independentemente de censura ou licença", ao que se soma, dentre os dispositivos diretamente relacionados com a liberdade de expressão, o artigo 206, inciso II, que dispõe sobre a liberdade de aprender, ensinar, pesquisar e divulgar o pensamento, a arte e o saber, ao passo que o artigo 220, estabelece que a manifestação do pensamento, a criação, a expressão e a informação, sob qualquer forma, processo ou veículo, não sofrerão qualquer restrição, observado o disposto nesta Constituição. 
AMARAL, Jordana Siteneski do; MACHADO, Deborah da Silva. Mídia, monopólio e democracia: um estudo sobre a monopolização da mídia no Brasil e porque isso pode ser uma ameaça à democracia. Revista Eletrônica Direito e Política, Programa de Pós-Graduação Stricto Sensu em Ciência Jurídica da UNIVALI, Itajaí, v.13, n.2, $2^{\circ}$ quadrimestre de 2018. Disponível em: www.univali.br/direitoepolitica - ISSN 1980-7791

comunicação pautada pela unilateralidade. Ao contrário dos demais, o Brasil insiste no silêncio ao invés de promover um amplo debate sobre o tema, e sempre que surge uma tentativa de discuti-lo rapidamente é repudiado, remetendo o debate à "censura", ou ao cerceamento à 'liberdade de imprensa'.

Em um estudo como este, que versará sobre comunicação e consequentemente, meios de comunicação de massa, será necessário esclarecer alguns conceitos, em especial o que se entende como "meios de comunicação de massa". Assim, se optou pela teoria proposta por John Thompson, que conceitua a comunicação de massa como sendo "a produção institucionalizada e difusão generalizada de bens simbólicos através da fixação e transmissão de informação ou conteúdo simbólico"6. Então, sempre que o termo "meio de comunicação de massa", "veículos de comunicação" ou ainda, somente "mídia" forem empregados, se está fazendo referência aos meios técnicos de difusão e produção de mensagens as quais podem ser disponibilizadas ou acessadas por um grande número de pessoas.

O problema de pesquisa que norteia este trabalho é responder, se a interferência do Estado na comunicação, por meio de uma regulamentação da mídia é um modo de assegurar a liberdade de expressão e, desta forma, contribuir para o aperfeiçoamento da democracia.

A metodologia de trabalho passa por uma revisão de literatura, com leituras especializadas (do Direito e das Comunicações) ou não (opiniões de jornalistas e especialistas do meio, expostas em blogs), de livros e publicações em meio virtual, artigos científicos, além de uma pesquisa feita em bancos de dados, relatórios e processos administrativos. O método de abordagem será o hipotético-dedutivo.

As hipóteses levantadas pretendem confrontar e dizer se a regulamentação dos meios de comunicação configura, ou não censura, ou se se trata de um mecanismo de aperfeiçoamento da democracia, ao assegurar a liberdade de expressão.

Para tanto, este artigo será trabalhado em cinco itens capítulos. No primeiro item vaise construir um panorama da mídia brasileira, examinando os motivos que levaram a seu formato atual, e analisar as problemáticas que envolvem os principais institutos

\footnotetext{
${ }^{6}$ THOMPSON, Jonh B.. A mídia e a modernidade: uma teoria social da mídia. 7a Edição, Petrópolis, RJ: Vozes, 2005, p.32.
} 
AMARAL, Jordana Siteneski do; MACHADO, Deborah da Silva. Mídia, monopólio e democracia: um estudo sobre a monopolização da mídia no Brasil e porque isso pode ser uma ameaça à democracia. Revista Eletrônica Direito e Política, Programa de Pós-Graduação Stricto Sensu em Ciência Jurídica da UNIVALI, Itajaí, v.13, n.2, 20 quadrimestre de 2018. Disponível em: www.univali.br/direitoepolitica - ISSN 1980-7791

normativos vigentes que versam sobre a comunicação social e as mídias de massa. No segundo item, o objetivo é demonstrar o conceito de esfera pública habermasiana e as consequências de uma associação do poder político com o poder midiático, e então analisar as concessões de rádio e tele difusão para parlamentares no exercício do mandato. Ainda, discute-se as problemáticas acerca dos principais institutos normativos que regulamentam a mídia vigentes.

No terceiro item, o trabalho discute a relação entre Liberdade de Expressão e Democracia, a partindo do modelo de democracia deliberativa proposto por Habermas. No quarto item, o objetivo é diferenciar as Liberdades de Expressão e de Imprensa. Por fim, no quinto item, o objetivo é analisar se a regulação dos meios de comunicação social é, uma forma de censura, tal como se manifestam empresas de comunicação e entidades (normalmente empresariais) da sociedade civil sendo, portanto, incompatível com a democracia.

\section{PANORAMA DA MÍdIA BRASILEIRA - A FORMAÇÃO DO OLIGOPÓLIO E O MONOPÓLIO DA INFORMAÇÃO}

Neste título serão apontadas características da mídia brasileira, as formas como os meios de comunicação estão organizados, bem como aspectos históricos e políticos que contribuíram para tal organização.

Recentemente, em 2016, dados apresentados por Belo e Ribeiro7 apontam que menos de dez famílias controlam hoje as comunicações no país, característica do oligopólio clássico - poucas empresas dominando determinado produto ou serviço, sem outras concorrentes no mercado. As concessões, de faixas de rádio e canais televisão, concentradas nas mãos dessas famílias tornaram-se verdadeiras "capitanias hereditárias", onde, apesar de ser vedada por lei, as concessões constituem herança, de geração para geração, formando uma casta de poderosos regionais.

\footnotetext{
7 BELLO, Enzo; RIBEIRO, Samantha S. Moura (orgs.). Os meios de comunicação no Brasil atual: entre a normatividade democrática da Constituição e a Realpolitk da mídia oligárquica. In: BELLO, Enzo; RIBEIRO, Samantha S. Moura (orgs.). Democracia nos meios de comunicação: Pluralismo, Liberdade de Expressão e Informação. Rio de Janeiro, Lumen Juris, 2016, p.6.
} 
AMARAL, Jordana Siteneski do; MACHADO, Deborah da Silva. Mídia, monopólio e democracia: um estudo sobre a monopolização da mídia no Brasil e porque isso pode ser uma ameaça à democracia. Revista Eletrônica Direito e Política, Programa de Pós-Graduação Stricto Sensu em Ciência Jurídica da UNIVALI, Itajaí, v.13, n.2, $2^{\circ}$ quadrimestre de 2018. Disponível em: www.univali.br/direitoepolitica - ISSN 1980-7791

Sobre a concentração das comunicações e telecomunicações no Brasil, Cabral ${ }^{8}$ explica que a Rede Globo de Televisão - família Marinho - (hoje Organizações Globo) é considerada o maior conglomerado de mídias no país ao qual estão subordinados, ou de sua 'propriedade', jornal (O Globo), rádio (Rádio Globo), a emissora de televisão (TV Globo), e exercendo influência em todas as regiões do país por meio de suas 'afiliadas'.

Mas além da Globo, a TV Record (da Igreja Universal do Bispo Edir Macedo) e o SBT (Sistema Brasileiro de Televisão, da família Abravanel/Sílvio Santos) também se destacam entre os principais conglomerados nacionais, chegando a quase todos os lares. A Rede Bandeirantes (família Saad) e a Rede TV (dos sócios Amílcare Dallevo Jr e Marcelo de Carvalho) também vêm trilhando o mesmo caminho.

No caso dos grupos regionais, evidencia-se: a RBS - Rede Brasil Sul - da família Sirotsky - (com emissoras de rádio AM e FM e jornais (Zero Hora, no Rio Grande do Sul, e Diário Catarinense, em Santa Catarina), alcançando todos os cantos dos dois estados do extremo sul do país; o Grupo Jaime Câmara (no Centro-Oeste), também tem rádio, jornal, televisão e internet, com a TV Anhanguera; a Rede Amazônica de Rádio e Televisão (fundada pelos sócios Phelipe Daou, Milton Magalhães Cordeiro e Joaquim Margarido), hoje atua como 'afiliada' da Rede Globo de Televisão, embora já tenha sido retransmissora da Rede Bandeirantes, e atua em cinco dos sete Estados da Região Norte; o Grupo Zahran (sob o comando de Ueze Zarhan) atua nos Estados Mato Grosso e Mato Grosso do Sul - assumiu recentemente a TV Anhanguera (Goiás e Tocantins) e várias regionais antes afiliadas à Globo; e, o SVM - Sistema Verdes Mares (concessão original feita a Moisés Pimentel, hoje é afiliada da Rede Globo de Televisão, com canais de tv, rádios $A M$ e FM, jornais e internet. Atua no Nordeste, tem sede no Estado do Ceará. Como se vê, e como explica Cabral, todos os grupos ou redes, de uma forma ou outra, vinculados à Rede Globo, ou à Rede Bandeirantes, ou ao SBT, retransmitindo suas grades de programação

A $\operatorname{EBC}^{9}$ (Empresa Brasileira de Comunicação - empresa pública federal de comunicação) foi criada para possibilitar um canal multivocal e caráter público, não governamental.

\footnotetext{
8 CABRAL, Eula Dantas Taveira. Mídia no Brasil: Concentração das Comunicações e Telecomunicações. In: Revista Eletrônica Internacional de Economia Política da Informação, da Comunicação e da Cultura, v. 17, n. 3, 2015, p.18. <https://seer.ufs.br/index.php/eptic/article/view/4298/pdf> Acesso em 27 de fevereiro de 2018
}

\footnotetext{
${ }^{9} \mathrm{Em}$ outubro de 2007, com a edição da Medida Provisória 398, depois convertida na Lei 11 652/2008, foi autorizada a criação da Empresa Brasil de Comunicação (EBC).A Empresa herdou os canais de rádio e TV geridos pela estatal Radiobrás e pela Associação de Comunicação Educativa Roquette-Pinto (Acerp). A EBC ficou encarregada de unificar e gerir as emissoras federais já existentes, instituindo o Sistema Público de Comunicação. Além disso, adquiriu como missão articular e implantar a Rede Nacional de Comunicação Pública. A Medida
} 
AMARAL, Jordana Siteneski do; MACHADO, Deborah da Silva. Mídia, monopólio e democracia: um estudo sobre a monopolização da mídia no Brasil e porque isso pode ser uma ameaça à democracia. Revista Eletrônica Direito e Política, Programa de Pós-Graduação Stricto Sensu em Ciência Jurídica da UNIVALI, Itajaí, v.13, n.2, $2^{\circ}$ quadrimestre de 2018. Disponível em: www.univali.br/direitoepolitica - ISSN 1980-7791

Embora seja cedo para afirmações, nesse breve espaço de tempo (da sua criação até 2018), já teve seu propósito desvirtuado, tornando-se pouco a pouco a voz institucionalizada, a do governo em exercício.

Os grupos familiares referidos acima mantêm o comando das redes e grupos por meio da sucessão, como se hereditária fosse. Claro exemplo é a RBS (Rede Brasil Sul de Comunicações) que já se encontra na terceira geração de "proprietários". Observe-se aqui, que a transferência da outorga de uma geração para outra, não está prevista em nenhum diploma legal, ou resolução de agência regulatória uma vez que se trata de concessão de serviço público, operando-se 'de fato', a política do "fato consumado". ${ }^{10}$

Essa verdadeira oligopolização das redes de TV é particularmente importante, considerando que o sistema de mídias no Brasil é organizado (e centralizado) a partir desse veículo, o quê, por sua vez, possibilitou o monopólio da comunicação, pois a televisão se apresenta como uma das principais, e em alguns casos, como a única fonte de informação e formação de opinião (monopólio) para a maior parte da população brasileira ${ }^{11}$.

Historicamente cabe ressaltar que o modelo das redes de televisão brasileiras foi estruturado seguindo o modelo do sistema norte americano, onde há uma programação conjunta ou uma grade fixa de programação, que deve ser transmitida por todas as emissoras que compõe a rede e são suas afiliadas. É modelo onde existe um "centro", uma "cabeça", ao qual todas as demais emissoras que a ele se vinculam, devem submeter-se. Este é o conceito de emissoras "cabeças de rede". Modelo esse que foi adotado no Brasil, ainda no período dos governos militares, com o intuito (na época, fundamental para o regime) de buscar a integração nacional ${ }^{12}$.

Provisória 744, publicada em 02 de setembro de 2016, convertida na Lei n. 13.417, de 1 de março de 2017, alterou a estrutura da Empresa. A EBC é vinculada à Secretaria-Geral da Presidência da República e administrada por um Conselho de Administração e por uma Diretoria Executiva. A Empresa conta, em sua composição, com um Conselho Fiscal e um Comitê Editorial e de Programação, órgão técnico de participação institucionalizada da sociedade, de natureza consultiva e deliberativa. Disponível em: http://www.ebc.com.br/institucional/sobre-a-ebc/o-que-e-aebc/2012/09/historico Acessado em: 23/6/2018

10 MARINONI, Bruno. Concentração dos meios de comunicação de massa e o desafio da democratização no país. Revista Análise, n¹3, Fundação Friedrich-Ebert-Stiffung (FES) Brasil, São Paulo: novembro, 2015, p.11. Disponível em: <http://intervozes.org.br/wp-content/uploads/2016/02/Projeto-FES-Artigo-concentracaomeio.pdf> Acesso em: 22 maio 2016.

${ }^{11}$ GUARESCHI, Pedrinho A.; BIZ, Osvaldo. Mídia e Democracia. Porto Alegre: 2005, p.46.

12 KLEIN, Otávio José. A notícia em rede: processos e práticas de produção da notícia em rede regional de televisão. Passo Fundo: Universidade de Passo Fundo, 2013, p.50. 
AMARAL, Jordana Siteneski do; MACHADO, Deborah da Silva. Mídia, monopólio e democracia: um estudo sobre a monopolização da mídia no Brasil e porque isso pode ser uma ameaça à democracia. Revista Eletrônica Direito e Política, Programa de Pós-Graduação Stricto Sensu em Ciência Jurídica da UNIVALI, Itajaí, v.13, n.2, $2^{\circ}$ quadrimestre de 2018. Disponível em: www.univali.br/direitoepolitica - ISSN 1980-7791

Antes de encerrar este tópico é importante destacar o trabalho realizado em 2017, pela Organização Não Governamental "Repórteres sem Fronteiras", em parceria com o Coletivo Brasil de Comunicação Social - INTERVOZES, que conduziu estudo, justamente sobre a propriedade e a concentração dos veículos de comunicação do Brasil. O mesmo projeto "Media Ownership Monitor", já foi realizado em vários países em que a ONG está presente, como por exemplo, México, Camboja, Tunísia, Ucrância, Turquia e Colômbia. O trabalho resultou no mapeamento da mídia brasileira, o que permitiu obter dados mais atualizados do cenário nacional ${ }^{13}$.

$\mathrm{Na}$ pesquisa foram analisados 50 veículos em quatro segmentos (TV, rádio, mídia impressa e online ${ }^{14}$ ), que pertencem a 26 grupos de comunicação. Desses, todos possuem mais de um tipo de veículo de mídia e 16 avançam seus negócios em outros setores, como produção cinematográfica, edição de livros, agência de publicidade, gravadoras, programação de TV a cabo, entre outros ${ }^{15}$ (RSF, 2017).

Cinco grupos ou seus proprietários individuais concentram mais da metade dos veículos: 9 pertencem ao Grupo Globo, 5 ao Grupo Bandeirantes, 5 à família Macedo (considerando o Grupo Record e os veículos da IURD, ambos do mesmo proprietário), 4 ao grupo de escala regional RBS e 3 ao Grupo Folha. Outros grupos aparecem na lista com dois veículos cada: Grupo Estado, Grupo Abril e Grupo Editorial Sempre Editora/Grupo SADA. Os demais grupos possuem apenas um veículo da lista. São eles: Grupo Sílvio Santos, Grupo Jovem Pan, Grupo Jaime Câmara, Diários Associados, Grupo de Comunicação Três, Grupo Almicare Dallevo \& Marcelo de Carvalho, Ongoing/Ejesa, BBC - British Broadcasting Corporation, EBC - Empresa Brasil de Comunicação, Publisher Brasil, Consultoria Empiricus, Grupo Alfa, Grupo Mix de Comunicação/Grupo Objetivo, Igreja Renascer em Cristo, Igreja Adventista do Sétimo Dia, Igreja

\footnotetext{
13 RSF, Repórteres sem fronteiras. Media Ownserhip Monitor Brasil. Disponível em:< http://brazil.momrsf.org/br/> Acesso em 08 de maio de 2018.

14 Mais precisamente, a análise contabilizou 11 redes de TV (aberta e por assinatura), 12 redes de rádio, 17 veículos de mídia impressa (jornais de circulação diária e revistas de circulação semanal) e 10 veículos online (portais de notícias). Foram selecionados com base na sua audiência e capacidade de agendamento, ou seja, seu potencial de influenciar a opinião pública.
}

${ }^{15}$ RSF, Repórteres sem fronteiras. Media Ownserhip Monitor Brasil. Disponível em:< http://brazil.momrsf.org/br/> Acesso em 08 de maio de 2018. 
AMARAL, Jordana Siteneski do; MACHADO, Deborah da Silva. Mídia, monopólio e democracia: um estudo sobre a monopolização da mídia no Brasil e porque isso pode ser uma ameaça à democracia. Revista Eletrônica Direito e Política, Programa de Pós-Graduação Stricto Sensu em Ciência Jurídica da UNIVALI, Itajaí, v.13, n.2, $2^{\circ}$ quadrimestre de 2018. Disponível em: www.univali.br/direitoepolitica - ISSN 1980-7791

Católica/Rede Católica de Rádio e INBRAC - Instituto Brasileiro de Comunicação Cristã ${ }^{16}$.

Além disso, dos 26 grupos formados, 21 grupos ou seus acionistas possuem atividades em outros setores econômicos, como educação, financeiro, imobiliário, agropecuário, energia, transportes, infraestrutura, política econômica das cidades, alimentação e saúde. Há ainda proprietários que são políticos ou lideranças religiosas: dos 50 veículos analisados, 5 direcionam todo o seu conteúdo para a defesa dos valores de sua religiosidade específica ${ }^{17}$.

Mesmo após mais de dez anos dos dados revelados pela pesquisa "Donos da Mídia"18 o grupo Globo ainda se coloca como líder absoluta no sistema de mídia de massa brasileiro. Apenas para ilustrar a abrangência do grupo, ele conta atualmente com 33 canais Globosat, 36,9\% da audiência televisiva, uma editora que publica 14 revistas, emissoras de rádio (Rádio Globo, CBN e mais 51 emissoras de rádio afiliadas no país inteiro), televisão por assinatura, portais na internet (Portal G1 é $5^{\circ}$ site mais acessado no Brasil), jornais impressos (O Globo, Extra). ${ }^{19}$

Suas receitas somam 17 bilhões de reais, figurando no ranking dos principais proprietários de mídia do mundo, o Zenith Top Thirty Global Media Owners, publicado desde 2007. Na edição de 2017 desse ranking, que leva em consideração apenas uma parte da receita dos conglomerados, o grupo alcançou a $19^{a}$ do ranking 20 .

\footnotetext{
${ }^{16}$ RSF, Repórteres sem fronteiras. Media Ownserhip Monitor Brasil. Disponível em: $<$ http://brazil.momrsf.org/br/> Acesso em 08 de maio de 2018.

17 RSF, Repórteres sem fronteiras. Media Ownserhip Monitor Brasil. Disponível em:< http://brazil.momrsf.org/br/> Acesso em 08 de maio de 2018.

18 Pesquisa citada em Lima (2015), Guareschi (2013) e Klein (2013). O projeto "Donos da mídia" consistiu em construir um banco de dados sobre os grupos de mídia no Brasil, compreendendo veículos impressos, eletrônicos e online. Foi idealizado pelo jornalista gaúcho Daniel Herz, morto em 2006; produzido em colaboração Instituto de Estudos e Pesquisas em Comunicação (Epcom), entidade parceira do Fórum Nacional pela Democratização da Comunicação (FNDC). Com a morte de Herz, em 2006, o projeto passou a ser liderado pelo também jornalista James Görgen. Os dados disponíveis foram obtidos por meio de um cruzamento de informações disponibilizadas pela Anatel, pelo Ministério das Comunicações. Hoje, 17 de maio de 2018, não é mais possível acessar o site do projeto, nem o encontrar através dos buscadores da web. O site saiu do ar em meados de setembro de 2016, mas seus dados podem ser encontrados em outros trabalhos publicados até esta data.
}

19 RSF, Repórteres sem fronteiras. Grupo Globo. Disponível em <http://brazil.momrsf.org/br/proprietarios/empresas/detail/company/company/show/grupo-globo/> Acesso em 17 de maio de 2018

20 RSF, Repórteres sem fronteiras. Grupo Globo. Disponível em <http://brazil.momrsf.org/br/proprietarios/empresas/detail/company/company/show/grupo-globo/> Acesso em 17 de maio de 2018 
AMARAL, Jordana Siteneski do; MACHADO, Deborah da Silva. Mídia, monopólio e democracia: um estudo sobre a monopolização da mídia no Brasil e porque isso pode ser uma ameaça à democracia. Revista Eletrônica Direito e Política, Programa de Pós-Graduação Stricto Sensu em Ciência Jurídica da UNIVALI, Itajaí, v.13, n.2, $2^{\circ}$ quadrimestre de 2018. Disponível em: www.univali.br/direitoepolitica - ISSN 1980-7791

Mas o Grupo Globo também é líder de audiência nos meios impressos, radiofônicos e nos portais de notícias na internet ${ }^{21}$. Isso ocorre porque em nosso país a propriedade cruzada é permitida, sendo esta outra característica que pode ser observada no cenário da comunicação. Com o fenômeno contemporâneo da convergência tecnológica22, ela tende a se agravar. No próximo item, esta questão será melhor detalhada.

Com base nessas considerações, ao que tudo indica, no caso das redes de comunicação do Brasil, há a configuração de oligopólio, mas que possui efeitos práticos e assume características de monopólio.

Mas não é apenas de veículos de comunicação que os monopólios se sustentam. Outra característica que se observa na comunicação brasileira, é a formação da chamada "propriedade cruzada", o que acentua ainda mais o problema da concentração e constituição de oligopólios ${ }^{23}$.

A propriedade cruzada ocorre, conforme Guareschi, quando o sistema permite que uma mesma empresa seja proprietária de jornal diário, rádio, televisão aberta e por assinatura na mesma localidade, o que se pode constatar já no título anterior, no entanto, alguns países como EUA, França e Inglaterra têm adotado medidas para impedir essa concentração, a fim de garantir certa pluralidade e assegurar competição ${ }^{24}$.

Como apontam os estudos aqui referidos, a propriedade cruzada não é exclusividade do cenário brasileiro, mesmo porque ela é fruto da globalização, do esfumaçamento das fronteiras e como tal, se faz presente em diversos países do planeta. Importante anotar, que se toma aqui, como referência para o fenômeno da globalização, de Santos ${ }^{25}$. Tal

${ }^{21}$ Tais indicadores também se encontram no relatório Media Ownership Brazil. Disponível em: http://brazil.mom$\mathrm{rsf}$.org/br/destaques/indicadores/?_escaped_fragment_=9fed61067e34232006ff7dcd0ed479d0\&cHash=1470265 3dd006e4faf46f9f57486cc3a> Acesso em 11 de maio de 2018

22 Com "convergência tecnológica", o trabalho refere-se à tendência atual no cenário midiático, de que um dispositivo de mídia, por reunir diferentes funções, pode agregar e distribuir um mesmo conteúdo em diferentes plataformas de mídia. Por exemplo, o jornal impresso que possui versão digital, ou a rádio que realiza streaming de sua programação em vídeo na internet.

${ }^{23}$ GUARESCHI, Pedrinho A.; BIZ, Osvaldo. Mídia e Democracia. Porto Alegre: 2005, p.47.

${ }^{24}$ MARTINS, Ana Luiza; DE LUCA, Tânia Regina. (Orgs.) História da Imprensa no Brasil. 2.ed.,1 1 a reimpressão, São Paulo: Contexto, 2012, p.271.

25 "[... Damos aqui alguns exemplos. Fala-se, por exemplo, em aldeia global para fazer crer que a difusão instantânea de notícias realmente informa as pessoas. A partir desse mito e do encurtamento das distâncias para aqueles que realmente podem viajar - também se difunde a noção de tempo e espaço contraídos. É como se o mundo se houvesse tornado, para todos, ao alcance da mão. Um mercado avassalador dito global é apresentado como capaz de homogeneizar o planeta quando, na verdade, as diferenças locais são aprofundadas". [...] "De fato, 
AMARAL, Jordana Siteneski do; MACHADO, Deborah da Silva. Mídia, monopólio e democracia: um estudo sobre a monopolização da mídia no Brasil e porque isso pode ser uma ameaça à democracia. Revista Eletrônica Direito e Política, Programa de Pós-Graduação Stricto Sensu em Ciência Jurídica da UNIVALI, Itajaí, v.13, n.2, $2^{\circ}$ quadrimestre de 2018. Disponível em: www.univali.br/direitoepolitica - ISSN 1980-7791

fenômeno, que não é recente, teve impulso nos anos 1970, com a chamada "Terceira Revolução Industrial". O surgimento de novas tecnologias de informação, eletrônica, informática e automação possibilitaram a propagação da informação por meio de redes, conferindo velocidade à informação e caráter de instantaneidade ${ }^{26}$.

A comunicação no século XX já era caracterizada pela atividade de conglomerados de comunicação. Esse caráter de conglomerados mundiais foi se consolidando ao longo do século passado, e cada vez mais tomava dimensões transnacionais ${ }^{27}$.

A política econômica neoliberal adotada pelos governos brasileiros foi em parte responsável pela formação dos oligopólios na mídia ${ }^{28}$. McChesney, que vem na mesma esteira, diz que a configuração do cenário midiático, mais do que uma consequência da globalização, é resultado do neoliberalismo, na medida em que este se caracteriza por ser um conjunto de políticas que trazem em seu âmago a reivindicação de "desregulamentar", ou 'manter a ausência' de regulamentação, o sistema de mídia comercial a fim de melhor atender os interesses corporativos ${ }^{29}$.

Recentemente foi noticiada duas das maiores "fusões", ou aquisições entre conglomerados de comunicação e entretenimento: AT\&T (gigante da telefonia) completa aquisição da Time Warner em negociação de US\$ 85 bilhões $^{30}$; e, a The Walt Disney Company comprou quase a totalidade da Fox (The 21th century Fox) correspondente à produção de conteúdo de cinema, TV e internet. ${ }^{31}$

para a grande maior parte da humanidade a globalização está se impondo como uma fábrica de perversidades". [...] "A perversidade sistêmica que está na raiz dessa evolução negativa da humanidade tem relação com a adesão desenfreada aos comportamentos competitivos que atualmente caracterizam as ações hegemônicas. Todas essas mazelas são direta ou indiretamente imputáveis ao presente processo de globalização". In: SANTOS, Milton. Por uma outra globalização: do pensamento único à consciência universal. 6 ed. - Rio de Janeiro: Record, 2001, p.18-20.

${ }^{26}$ GUARESCHI, Pedrinho A.; BIZ, Osvaldo. Mídia e Democracia. Porto Alegre: 2005, p.39.

27 THOMPSON, Jonh B.. A mídia e a modernidade: uma teoria social da mídia. 7a Edição, Petrópolis, RJ: Vozes, 2005, p.144.

${ }^{28}$ GUARESCHI, Pedrinho A.; BIZ, Osvaldo. Mídia e Democracia. Porto Alegre: 2005, p.41.

${ }^{29}$ MCCHESNEY, Robert W. Mídia global, neoliberalismo e imperialismo. In: MORAES, Dênis de (org.). Por uma outra comunicação. $2^{\mathrm{a} e d .,}$ Rio de Janeiro: Record, 2004, p.248.

30 Maiores informações em: https://www.tecmundo.com.br/mercado/131330-compra-time-warner-attcompletada.htm; e, https://oglobo.globo.com/economia/att-conclui-aquisicao-da-time-warner-22781917 Acessados em: 25/6/2018

31 Mais informações em: https://meiobit.com/377144/disney-compra-fox-52-4-bilhoes-de-dolares/; e, https://exame.abril.com.br/negocios/por-que-a-disney-comprou-a-fox-dona-de-x-men-e-deadpool/ Acessados em: $25 / 6 / 2018$ 
AMARAL, Jordana Siteneski do; MACHADO, Deborah da Silva. Mídia, monopólio e democracia: um estudo sobre a monopolização da mídia no Brasil e porque isso pode ser uma ameaça à democracia. Revista Eletrônica Direito e Política, Programa de Pós-Graduação Stricto Sensu em Ciência Jurídica da UNIVALI, Itajaí, v.13, n.2, $2^{\circ}$ quadrimestre de 2018. Disponível em: www.univali.br/direitoepolitica - ISSN 1980-7791

Dessa forma pode-se avançar e identificar, no período da Ditadura Militar no Brasil (6485), além da concentração e regionalização do oligopólio de mídia, o surgimento do monopólio da informação.

Embora alguma concentração já existisse antes da Ditadura Militar de 1964, é naquele período que se fortalecem e consolidam, eis que quando os militares tomaram o poder, aprofundaram a presença do Estado no sistema de comunicações ${ }^{32}$. O sistema de redes de televisão foi estruturado para atingir grandes audiências, alcançar o maior número de pessoas possível. As empresas de comunicação, de rádio e televisão passaram a "retransmissoras", e serviram de instrumento para, os já grandes grupos locais ou regionais - os chamados 'cabeças de rede' - pudessem abranger todo o território nacional $^{33}$. O modelo constituído por redes possibilitou que os brasileiros sintonizassem (praticamente) um mesmo canal (especialmente Globo) e assistissem a um mesmo programa, com linguagem uniforme, modismos, comportamentos 'morais', alcançando altíssimos índices de audiência ${ }^{34}$, o que viabilizava duas intenções: o retorno político para o governo - e econômico para as emissoras.

Logo, a formação de um sistema de mídias organizado em grandes redes demonstrouse uma estratégia de grande valia para as empresas de mídia, bem como ao próprio regime. Essas redes que concentraram as concessões e a propriedade de veículos de comunicação foram incentivadas pelo regime, visto que lhe servia muito bem, já que tinha interesse em transmitir uma mesma mensagem ou discurso para um grande número de pessoas. Ademais, a hegemonia facilitaria o controle do conteúdo e das mensagens que eram propagadas. E isso foi possível graças a associação do poder político com o poder da mídia.

Se essa associação foi importante para a manutenção da Ditadura até $1985^{35}$, quando a mídia já não conseguia mais esconder as mobilizações populares contra o regime (os

32 GUARESCHI, Pedrinho A.; BIZ, Osvaldo. Mídia e Democracia. Porto Alegre: 2005, p. 37.

33 GUARESCHI, Pedrinho A.; BIZ, Osvaldo. Mídia e Democracia. Porto Alegre: 2005, p. 37.

${ }^{34}$ KLEIN, Otávio José. A notícia em rede: processos e práticas de produção da notícia em rede regional de televisão. Passo Fundo: Universidade de Passo Fundo, 2013, p.16.

35 Notícias sobre os comícios disponíveis em: http://acervo.oglobo.globo.com/rio-de-historias/comicio-dasdiretas-ja-levou-um-milhao-de-pessoas-candelaria-em-1984-8883947 ; e , http://www.ibope.com.br/pt$\mathrm{br} /$ noticias/Paginas/Comicio-Diretas-Ja-no-Rio-de-Janeiro-completa-29-anos.aspx ; e, https://www.cartamaior.com.br/?/Editoria/Politica/Os-30-anos-do-comicio-que-a-Globo-transformou-em-festa/4/30084 ; e, https://www1.folha.uol.com.br/fsp/brasil/fc1604200419.htm ; e, https://www1.folha.uol.com.br/fsp/brasil/fc2501200412.htm https://acervo.estadao.com.br/noticias/topicos, diretas-ja,874,0.htm 
AMARAL, Jordana Siteneski do; MACHADO, Deborah da Silva. Mídia, monopólio e democracia: um estudo sobre a monopolização da mídia no Brasil e porque isso pode ser uma ameaça à democracia. Revista Eletrônica Direito e Política, Programa de Pós-Graduação Stricto Sensu em Ciência Jurídica da UNIVALI, Itajaí, v.13, n.2, $2^{\circ}$ quadrimestre de 2018. Disponível em: www.univali.br/direitoepolitica - ISSN 1980-7791

grandes jornais locais Rio de Janeiro, São Paulo e Porto Alegre, e a Rede Globo de Televisão, acabaram 'mostrando' os comícios gigantes), numa democracia, então, fica mais evidente ao considerar-se que ela (associação) possui o condão de definir a agenda pública, tal como propõe a "Teoria do Agendamento". Neste sentido, os veículos podem definir quais serão os temas da discussão pública. Isso se dá quando chama-a atenção do público para determinados assuntos e tópicos, levando a coletividade a refletir (e possivelmente agir) conforme propagado, sendo este o "primeiro estágio da opinião pública"36.

Mas as consequências do agendamento da mídia podem ir muito além: ela influencia comportamentos, transmite culturas e - talvez o aspecto mais contundente - gera consensos sociais. Não obstante, estudos mostram que quanto maior é a exposição dos sujeitos à mídia, mais unânimes (ou uniformizadas) são as opiniões do público sobre determinado assunto ${ }^{37}$.

Isso se transmite para a política, uma vez que, por exemplo, as pesquisas eleitorais não raras vezes, conseguem demonstrar que um candidato, seja ele de direita ou esquerda, consegue se eleger se figurar cotidianamente na grande mídia, pois ela parece ter o poder de atribuir àquelas pessoas valores e atitudes positivos (ou negativos) ${ }^{38}$.

Logo, percebe-se porque a mídia desperta tanto interesse nos políticos: 44 dentre os 594 congressistas no mandato 2012/2015 detinham outorgas de radiodifusão em seu nome. Esse número refere-se apenas às outorgas documentadas e referentes aos serviços de radiodifusão, não englobando os parlamentares que se utilizaram ou utilizam dos tristemente famosos "laranjas", nem aos parlamentares estaduais e municipais $^{39}$. Isso tudo ignorando o art. 54 da Constituição Federal de 1988 que proíbe expressamente que Deputados e Senadores não podem manter ou firmar contrato com

https://politica.estadao.com.br/noticias/eleicoes, ha-tres-decadas-40-mil-no-primeiro-comicio-das-diretas-imp,1117448; Acessados em: 25/6/2018

36 McCOMBS, Maxwell. A teoria da Agenda: mídia e opinião pública. Petrópolis, Rio de Janeiro: Vozes, 2009, p.188.

37 McCOMBS, Maxwell. A teoria da Agenda: mídia e opinião pública. Petrópolis, Rio de Janeiro: Vozes, 2009.

38 GUARESCHI, Pedrinho A. O direito humano a comunicação: pela democratização da mídia. Rio de Janeiro: Vozes, 2013, p.35.

39 MARINONI, Bruno. Concentração dos meios de comunicação de massa e o desafio da democratização no país. Revista Análise, nº13, Fundação Friedrich-Ebert-Stiffung (FES) Brasil, São Paulo: novembro, 2015 , p.22. Disponível em: <http://intervozes.org.br/wp-content/uploads/2016/02/Projeto-FES-Artigo-concentracaomeio.pdf> Acesso em: 22 maio 2016 
AMARAL, Jordana Siteneski do; MACHADO, Deborah da Silva. Mídia, monopólio e democracia: um estudo sobre a monopolização da mídia no Brasil e porque isso pode ser uma ameaça à democracia. Revista Eletrônica Direito e Política, Programa de Pós-Graduação Stricto Sensu em Ciência Jurídica da UNIVALI, Itajaí, v.13, n.2, $2^{\circ}$ quadrimestre de 2018. Disponível em: www.univali.br/direitoepolitica - ISSN 1980-7791

empresas de economia mista e concessionárias de serviço público (caso dos canais de rádio e televisão). Também, na sequência, o art. 55, inciso "I", prevê a perda do mandato para aquele que infringir aquelas vedações. Ao que parece, a previsão da sanção não é suficiente para coibir tal prática, tendo em vista os inúmeros casos existentes e comprovados, conforme se verá a seguir.

A inconstitucionalidade das concessões de trinta (30) Deputados Federais e oito (8) Senadores foi questionada em Arguição de Descumprimento de Preceito Fundamental - ADPF no 37940, protocolada em dezembro de 2015 pelo Partido Socialismo e Liberdade (PSol), em conjunto com o já citado Intervozes (Coletivo Brasil de Comunicação Social) ${ }^{41}$.

Indo na contramão daquilo que estabelece a Constituição, em novembro de 2016 o presidente Michel Temer ingressou no Supremo Tribunal Federal com outra ADPF pedindo que o tribunal se manifeste pela constitucionalidade das concessões de rádio e televisão aos parlamentares em exercício. ${ }^{42}$

Tal situação levou a uma deturpação da função da mídia na construção da cidadania e em uma política que garanta a liberdade. Não mais se reconhece a mídia parte integrante da verdadeira política (grifo do autor), que compreende espaços livres para o discurso e a fala, onde os indivíduos se realizem como cidadãos em sua totalidade e autenticidade ${ }^{43}$.

\subsection{ESFERAS PÚBLICAS MIDIATIZADAS}

No que diz respeito às esferas públicas midiatizadas, pode-se hoje, considerar os meios de comunicação, como "extensões da esfera pública", uma vez que é por meio deles

\footnotetext{
${ }^{40}$ Parecer do Ministério Público Federal. Disponível em: http://www.mpf.mp.br/pgr/documentos/adpf-379/view Acessado em: 25/6/2018

41 INTERVOZES. Ação elaborada por Intervozes e PSOL questiona no STF constitucionalidade do controle de emissoras de rádio e TV por políticos. Coletivo Brasil de Comunicação Social: 06 de dezembro de 2015. Acesso em: 23 agosto 2016. Disponível em: <http://intervozes.org.br/acao-elaborada-por-intervozes-epsol-questiona-no-stf-constitucionalidade-do-controle-de-emissoras-por-politicos/ > Acesso em: 17 setembro
} 2016.

42 Michel Temer vai ao Supremo a favor da concessão de rádio e TV a parlamentares. Notícia Conjur. Disponível em: <https://www.conjur.com.br/2016-nov-11/temer-stf-favor-concessao-radio-tv-politicos> Acesso em 27 de fevereiro de 2018.

${ }^{43}$ GUARESCHI, Pedrinho A. O direito humano a comunicação: pela democratização da mídia. Rio de Janeiro: Vozes, 2013, p.93. 
AMARAL, Jordana Siteneski do; MACHADO, Deborah da Silva. Mídia, monopólio e democracia: um estudo sobre a monopolização da mídia no Brasil e porque isso pode ser uma ameaça à democracia. Revista Eletrônica Direito e Política, Programa de Pós-Graduação Stricto Sensu em Ciência Jurídica da UNIVALI, Itajaí, v.13, n.2, $2^{\circ}$ quadrimestre de 2018. Disponível em: www.univali.br/direitoepolitica - ISSN 1980-7791

que a sociedade pode (poderá), ou não participar ativamente da vida política da sociedade.

A esfera pública na concepção de Habermas se consolida na virada do século XVIII operando politicamente na Inglaterra, com o início da publicação de relatórios dos debates que aconteciam no parlamento nos jornais britânicos, a partir de 1716 . Foi o chamado "breach of privilegie", que demarca uma transformação na forma como se dá a participação da sociedade na vida política. O parlamento inglês foi chamado a responder perante o fórum do público, e nas palavras de Habermas: "Através disso, o poder público torna-se público em duplo sentido"44.

Alguns autores como Thompson divergem em alguns pontos em relação à teoria de Habermas no que diz respeito à passividade da audiência, pois argumenta que os receptores dos produtos midiáticos são vistos com demasiada passividade pelo sociólogo 45 .

Indo de Thompson diretamente a Habermas, verifica-se que a crítica de Habermas aos meios de comunicação mais recentes (rádio, cinema e televisão) também se dá na seara da comercialização da imprensa, com a sua consequente concentração e centralização, o que ocasionou, segundo ele, uma mudança estrutural na mesma e ameaçou as funções críticas do jornalismo. Devido a essa industrialização da imprensa, houve a invasão dos meios de comunicação pela propaganda comercial, junto com a tendência a concorrência monopolista e a formação de conglomerados voltados à produção em massa ${ }^{46}$.

A este fenômeno de mercantilização e comercialização da imprensa, Habermas denominou de "refeudalização" da esfera pública", no qual a esfera pública burguesa assume novamente um caráter feudal, em que a integração do entretenimento de

\footnotetext{
${ }^{44}$ HABERMAS, Jürgen. Mudança estrutural da Esfera Pública: investigações quanto a uma categoria da sociedade burguesa. Tradução de Flávio R. Kothe. Rio de Janeiro: Tempo Brasileiro, 1984, p.78-80.

45 THOMPSON, Jonh B.. A mídia e a modernidade: uma teoria social da mídia. 7a Edição, Petrópolis, RJ: Vozes, 2005, p.72.

46 HABERMAS, Jürgen. Mudança estrutural da Esfera Pública: investigações quanto a uma categoria da sociedade burguesa. Tradução de Flávio R. Kothe. Rio de Janeiro: Tempo Brasileiro, 1984, p.120.
} 
AMARAL, Jordana Siteneski do; MACHADO, Deborah da Silva. Mídia, monopólio e democracia: um estudo sobre a monopolização da mídia no Brasil e porque isso pode ser uma ameaça à democracia. Revista Eletrônica Direito e Política, Programa de Pós-Graduação Stricto Sensu em Ciência Jurídica da UNIVALI, Itajaí, v.13, n.2, $2^{\circ}$ quadrimestre de 2018. Disponível em: www.univali.br/direitoepolitica - ISSN 1980-7791

massa e a publicidade tomam o lugar da crítica referente a questões públicas relevantes, abrindo espaço para a dominação política da população ${ }^{47}$.

Ademais, o próprio Habermas reconheceu que a esfera pública foi estendida aos meios de comunicação em sua obra Mudança Estrutural da Esfera Pública: "A refuncionalização do princípio da esfera pública baseia-se numa reestruturação da esfera pública em uma esfera que pode ser apreendida na evolução de sua instituição por excelência: a imprensa"48.

Logo, pode-se concluir que os meios de comunicação de massa constituem uma soma de espaços que são públicos, e devem ser usados para debater as questões pertinentes à sociedade, para exercer a política e a cidadania.

Se no passado os cidadãos atenienses se reuniam no àgora para exercer a cidadania e tomar decisões políticas hoje os meios de comunicação assumem este papel. Com o surgimento da democracia indireta, os meios de comunicação ganham uma importância particular, pois eles possibilitam o cruzamento das discussões que acontecem em todos os campos do país. Os meios de comunicação hoje se apresentam como a praça pública, são o àgora que transcende a limitação dos espaços físicos e temporais.

Embora a estruturação da comunicação brasileira em oligopólios seja decorrente de diversos fatores, um dos principais óbices encontrados para sua democratização dize respeito a legislação. Na verdade, a ausência de regulamentação no setor é fator determinante para o fortalecimento dos poucos grupos de mídia (oligopólio), o que produz enorme distorção na produção de informação e de formação de opinião (monopólio do discurso). Existem poucos institutos infraconstitucionais, que embora em vigor, recepcionados pela Constituição de 1988, são obsoletos, pois as comunicações evoluíram de tal forma e em velocidade tão absurda, que o fato de não passarem por atualizações têm lacunas que prejudicam sua aplicação prática.

Antes mesmo da promulgação da Constituição Federal de 1988 os problemas da ausência de regulamentação da comunicação social já haviam sido observados. Com a redemocratização do país, em que pese a Constituição de 1988 tenha recepcionado o

\footnotetext{
47 HABERMAS, Jürgen. Mudança estrutural da Esfera Pública: investigações quanto a uma categoria da sociedade burguesa. Tradução de Flávio R. Kothe. Rio de Janeiro: Tempo Brasileiro, 1984, p.229.

48 HABERMAS, Jürgen. Mudança estrutural da Esfera Pública: investigações quanto a uma categoria da sociedade burguesa. Tradução de Flávio R. Kothe. Rio de Janeiro: Tempo Brasileiro, 1984, p.213.
} 
AMARAL, Jordana Siteneski do; MACHADO, Deborah da Silva. Mídia, monopólio e democracia: um estudo sobre a monopolização da mídia no Brasil e porque isso pode ser uma ameaça à democracia. Revista Eletrônica Direito e Política, Programa de Pós-Graduação Stricto Sensu em Ciência Jurídica da UNIVALI, Itajaí, v.13, n.2, $2^{\circ}$ quadrimestre de 2018. Disponível em: www.univali.br/direitoepolitica - ISSN 1980-7791

tema da comunicação social, a sistemática não foi suficiente para romper com a estrutura oligopólica consolidada e que levou ao atual monopólio do discurso.

A Assembleia Constituinte, enquanto elaborava e votava o texto constitucional por meio de comissões e subcomissões permitiu, que os "proprietários" das grandes mídias se fizessem presentes durante o processo, usando sua força e indicando os integrantes dessas comissões e subcomissões ${ }^{49}$.

Logo, o processo de democratização não chegou a repercutir na comunicação. Os privilégios que antes eram concedidos pelos militares não só continuaram, mas também fizeram surgir no interior do país milhares de "coronéis eletrônicos"50", isto é, grandes empresários que usam a comunicação como um instrumento para atender seus desideratos políticos e partidários, esquecendo-se daquilo que torna uma comunicação democrática: a pluralidade de ideias ${ }^{51}$.

Outro óbice encontrado no caminho da democratização da comunicação diz respeito ao sistema de concessões e outorgas de radio/tele difusão também recepcionado. Estabelece o artigo 21, incisos XI e XII "a", da Constituição Federal de 1988 que compete a União explorar os serviços de telecomunicações e radiodifusão de sons e imagens, de forma direta ou indireta, por meio de concessão, autorização ou permissão. Assim, o artigo 21 perpetuou o sistema de concessões e outorgas pelo poder público a empresas particulares, sistema que vinha desde 1930, com o Decreto

49 GUARESCHI, Pedrinho A. O direito humano a comunicação: pela democratização da mídia. Rio de Janeiro: Vozes, 2013, p.45.

50 O termo "coronelismo eletrônico" é utilizado por pesquisadores para se referir ao fenômeno das concessões de rádio e televisão como "moeda de troca" e de barganha política. O sistema de concessões possibilitou a utilização da comunicação como "moeda de troca", no qual as concessões funcionam como uma espécie de "recompensa antecipada"50. O fenômeno em questão remete ao Brasil urbano da segunda metade do século 20. Ele sofre algumas mudanças com a promulgação da Constituição de 1988, mas persiste e se reafirma depois dela. Fatores como o modelo de concessões e outorgas da União a empresas privadas para exploração dos serviços públicos de comunicação na televisão e rádio, e principalmente, a centralização gradativa da mídia brasileira durante o período militar (1964-1985) foram fatores decisivos para a configuração do fenômeno ${ }^{50}$. Aqui, a "moeda de troca" continua sendo o voto da população, como no coronelismo do voto de cabresto. Mas não mais visando a posse de terra, e sim o controle de informação Ver: LIMA, Venícios A. de Lima. As "brechas" legais do coronelismo eletrônico. Revista Aurora, vol. 1, São Paulo: PUC/SP, 2007, p.44. Disponível em: <http://revistas.pucsp.br/index.php/aurora/article/viewFile/6344/4652> Acesso em: 21 maio 2016; LIMA, Venício A de; LOPES, Cristiano Aguiar. Coronelismo Eletrônico de novo tipo (1999-2004): as autorizações de emissoras como moeda de barganha política. São Paulo: Instituto para o Desenvolvimento do Jornalismo (Projor), 2007, p.4. Disponível em: <http://www.observatoriodaimprensa.com.br/download/Coronelismo_eletronico_de_novo_tipo.pdf> Acesso em: 19 outubro 2015

${ }^{51}$ GUARESCHI, Pedrinho A.; BIZ, Osvaldo. Mídia e Democracia. Porto Alegre: 2005, p.50. 
AMARAL, Jordana Siteneski do; MACHADO, Deborah da Silva. Mídia, monopólio e democracia: um estudo sobre a monopolização da mídia no Brasil e porque isso pode ser uma ameaça à democracia. Revista Eletrônica Direito e Política, Programa de Pós-Graduação Stricto Sensu em Ciência Jurídica da UNIVALI, Itajaí, v.13, n.2, $2^{\circ}$ quadrimestre de 2018. Disponível em: www.univali.br/direitoepolitica - ISSN 1980-7791

no 20.04752. Em tal modelo chamado de Trusteeship Mode/53, o grande detentor da comunicação é o Poder Público, mas quem o executa, em nome do primeiro, é o setor privado.

O modelo de concessão perdura porque a União considera o espectro eletromagnético um "bem público", que deve ser administrado pelo Estado, que pode ser cedida a particulares através das concessões, como serviços públicos ${ }^{54}$.

Contudo, a ausência de uma regulamentação que freasse a concentração, fez com que os interesses privados (sejam eles de cunho econômico ou político, ou ainda ambos) sejam sobrepostos aos interesses da coletividade (interesse público), isto é, o direito inerente à comunicação e à expressão, à diversidade de ideias, bem como à pluralidade de discursos, pressuposto para uma sociedade ser considerada democrática. Em outras palavras, o sistema é "mascarado e vestido" para parecer democrático, mas que é monopólico, e produz e repercute interesses, não raras vezes, estranhos e prejudiciais à sociedade.

No art. 223, § 20 da CF/1988 as concessões que deveriam ter caráter temporário, adquiriram feições de perpetuidade: ao exigir-dois quintos de votação nominal, qual o parlamentar que votará contra a renovação de um canal de rádio ou televisão? Caso o fizesse, sem dúvida seria "esquecido", e sumiria do espaço social, algo que é muito caro para um político55.

O texto Constitucional ainda reserva o Capítulo $\mathrm{V}$ para tratar especificamente sobre o tema da Comunicação Social, distribuindo em quatro dispositivos (art. 220 ao art. 224) as diretrizes e princípios que devem nortear a comunicação no Brasil. Tais dispositivos

52 GUARESCHI, Pedrinho A. O direito humano a comunicação: pela democratização da mídia. Rio de Janeiro: Vozes, 2013, p.45, p.40.

53 Trusteeshipmodel: na tradução literal, o termo significa "curadoria", "administração" (Dic. MICHAELIS). Neste modelo, a União outorgas às empresas privadas de comunicação a exploração dos serviços públicos de rádio e televisão, por meio de concessões. O Poder Executivo detém as concessões, mas quem executa os serviços de radiodifusão, televisão e telecomunicações é o setor privado. In: LIMA, Venícios A. de Lima. As "brechas" legais do coronelismo eletrônico. Revista Aurora, vol. 1, São Paulo: PUC/SP, 2007, p.44. Disponível em: <http://revistas.pucsp.br/index.php/aurora/article/viewFile/6344/4652> Acesso em: 21 maio 2016, p.3.

${ }^{54}$ BRITTOS, Valério Cruza. COLLAR, Marcello Scmitz. Direito à comunicação e democratização no Brasil. In: SARAIVA, Enrique; MARTINS, Paulo Emílio Matos; In: PIERANTI, Octavio Penna (Orgs.) Democracia e regulação dos meios de comunicação de massa. In: Rio de Janeiro: Editora FGV, 2008, p.72.

55 GUARESCHI, Pedrinho A. O direito humano a comunicação: pela democratização da mídia. Rio de Janeiro: Vozes, 2013, p.45. 
AMARAL, Jordana Siteneski do; MACHADO, Deborah da Silva. Mídia, monopólio e democracia: um estudo sobre a monopolização da mídia no Brasil e porque isso pode ser uma ameaça à democracia. Revista Eletrônica Direito e Política, Programa de Pós-Graduação Stricto Sensu em Ciência Jurídica da UNIVALI, Itajaí, v.13, n.2, $2^{\circ}$ quadrimestre de 2018. Disponível em: www.univali.br/direitoepolitica - ISSN 1980-7791

enfrentam problemas para ser implementados na prática, pela falta de regulamentação posterior.

O § $5^{\circ}$ do artigo 220 da Constituição de 1988 talvez seja o caso mais grave da ausência de regulamentação. Ele estabelece que: "Os meios de comunicação não podem, direta ou indiretamente, ser objeto de monopólio e oligopólio." O artigo foi uma das reivindicações da Ação Direta de Inconstitucionalidade por Omissão do Congresso Nacional, a ADO 4475, que questiona exatamente a indiferença do poder público em relação ao combate aos monopólios ${ }^{56}$.

O artigo 224 da Constituição Federal estabeleceu que para auxiliar o Congresso Nacional na tarefa de realizar as renovações, cancelamentos e novas concessões um órgão seria instituído: o Conselho Nacional de Comunicação Social. Tal conselho foi realmente estruturado por meio da Lei 8.389 de 30 de dezembro de 1999, no entanto, embora tal conselho tivesse competência para realizar tarefas, como por exemplo, realizar estudos sobre a concentração e as concessões de outorgas de veículos de comunicação, e que funcionaria como único órgão auxiliar do Congresso Nacional, até 2002 nunca tinha se reunido para discutir uma única pauta.

A questão fundamental se embasa na constatação de que inexiste uma verdadeira democracia no sistema de comunicação no país. É fato notório que os monopólios e oligopólios constituem uma agressão a liberdade de produção e comercialização, e é exatamente por isso que eles são proibidos pela regulamentação de todos os países democráticos 57 .

Muito mais do que um oligopólio nos moldes econômicos, trata-se do monopólio de bens muito mais valiosos e caros: a comunicação, a produção da informação. As sociedades contemporâneas formam suas opiniões, muito a partir da mídia. Definem seus valores, suas reivindicações e organizam a pauta social. A comunicação é um bem especial, tem dimensões sociais e simbólicas ${ }^{58}$.

\footnotetext{
${ }^{56}$ GUARESCHI, Pedrinho A. O direito humano a comunicação: pela democratização da mídia. Rio de Janeiro: Vozes, 2013, p.51.

57 GUARESCHI, Pedrinho A. O direito humano a comunicação: pela democratização da mídia. Rio de Janeiro: Vozes, 2013, p.52.

58 GUARESCHI, Pedrinho A. O direito humano a comunicação: pela democratização da mídia. Rio de Janeiro: Vozes, 2013, p.52.
} 
AMARAL, Jordana Siteneski do; MACHADO, Deborah da Silva. Mídia, monopólio e democracia: um estudo sobre a monopolização da mídia no Brasil e porque isso pode ser uma ameaça à democracia. Revista Eletrônica Direito e Política, Programa de Pós-Graduação Stricto Sensu em Ciência Jurídica da UNIVALI, Itajaí, v.13, n.2, $2^{\circ}$ quadrimestre de 2018. Disponível em: www.univali.br/direitoepolitica - ISSN 1980-7791

Para citar alguns exemplos, até já referidos aqui, de outras sociedades democráticas onde existe regulação da mídia, nos Estados Unidos, a propriedade cruzada é proibida59. Os países que compõem o Reino Unido, a Alemanha, a França, e os EUA têm agências reguladoras, que atuam como orgãos verdadeiramente independentes para regulamentar, organizar e cuidar da gestão do espectro eletroeletrônico. Nessas sociedades, a regulação não representa censura e cerceamento à liberdade. Ao contrário, ela é vista como um direito da sociedade de receber produtos midiáticos de qualidade, além de evitar a formação de monopólios ${ }^{60}$.

Na América Latina, há precedentes no mesmo sentido: na Argentina, o marco regulatório veio em 2009, com a elaboração de uma lei que "fixa um limite de licenças e a área de atuação do setor por cada pessoa que assuma um investimento". A Ley de Medios foi sancionada no governo de Cristina Kirchner ${ }^{61}$ e dentre seus objetivos estão a "promoção, desconcentração e fomento da concorrência com o fim de baratear, democratizar e universalizar a comunicação". Agora, em 2018, após uma pressão avassaladora dos 'donos das mídias', o novo governo, de Mauricio Machri, retrocedeu.

A partir do que foi exposto até o momento, percebe-se que a luta pela democratização da mídia enfrenta muitos empecilhos, e os problemas anotados até aqui são apenas são alguns deles. Quem mais perde com a omissão e conivência do poder público é a sociedade que amarga com uma democracia que em realidade, é incompleta.

\section{A DEMOCRACIA DELIBERATIVA DE hABERMAS E A IMPORTÂNCIA DO DISCURSO}

A comunicação e a opinião pública assumem uma particular importância no modelo de democracia deliberativa proposto por Habermas. Considerando que "o processo de

59 BANDEIRA, Luiza; CORRÊA, Alessandra; CARMO, Márcia; JARDIM Claudia. Como funciona a regulamentação da mídia em outros países? BBC Brasil Notícia. 2014, Disponível em: <http://www.bbc.com/portuguese/noticias/2014/12/141128_midia_paises_lab> Acesso em: 07 de setembro de 2015

60 MIELKE, Ana Cláudia. Órgãos reguladores dependentes: um caminho para equacionar direitos. In: VARJÃO, Suzana. Violações de direitos na mídia brasileira: um conjunto de reflexões sobre como coibir violações de direitos no campo da comunicação de massa. Brasília, DF: ANDI, 2015. Arquivo PDF disponível em: <http://intervozes.org.br/wp-content/uploads/2015/06/guia_violacoes_volumeii_web-1.pdf> Acesso em: 22 maio de 2016.

61 Com a assunção da presidência em 10 de dezembro de 2015 por Maurício Macri, houveram significativas mudanças na Ley de Medios. Ainda em dezembro de 2015, o presidente através de sucessivos decretos dissolveu as agências reguladoras, reduziu os mecanismos de combate à monopolização e destituiu autoridades que atuavam nos órgãos reguladores e tinham mandato até 2017. 
AMARAL, Jordana Siteneski do; MACHADO, Deborah da Silva. Mídia, monopólio e democracia: um estudo sobre a monopolização da mídia no Brasil e porque isso pode ser uma ameaça à democracia. Revista Eletrônica Direito e Política, Programa de Pós-Graduação Stricto Sensu em Ciência Jurídica da UNIVALI, Itajaí, v.13, n.2, $2^{\circ}$ quadrimestre de 2018. Disponível em: www.univali.br/direitoepolitica - ISSN 1980-7791

política deliberativa constituiu o âmago do processo democrático", a democracia em Habermas, assume uma interpretação diferenciada dos modelos de "democracia tradicionais"62.

Para o autor, a ideia de uma democracia que se apoie no discurso parte da premissa de uma "sociedade descentrada", onde a democracia em conjunto com a esfera pública política constituem uma arena para o debate, a percepção e tratamento dos problemas da sociedade 63 .

A teoria do discurso, na qual se funda a democracia deliberativa, reconhece os processos de comunicação e da formação da opinião e da vontade como a principal forma de "racionalização das decisões de um governo", onde a administração do Estado opera sob a égide do direito e da lei.

Se a função do poder político é voltada para decisões que vinculem a coletividade, então as estruturas comunicativas da esfera pública são uma rede abrangente, que funcionam como sensores que captam e a reagem à pressão de demandas da sociedade, estimulando opiniões influentes. Embora a opinião pública não possa "dominar" por si mesma o uso do poder administrativo, quando ela é transformada em "poder comunicativo", ela pode influenciá-1064.

Nesse sentido, os procedimentos democráticos se realizam por meio de redes comunicacionais constituídas pelas esferas públicas políticas, e é nelas que ocorre a formação da opinião pública acerca dos temas relevantes para a sociedade e que demandem regulamentação65.

A partir dessas considerações percebe-se que no conceito explorado por Habermas, mais do que simplesmente a liberdade de votar, a democracia deliberativa baseada na teoria do discurso implica na necessidade de comunicação. É através dos processos comunicativos que os indivíduos poderão, por meio do mútuo entendimento, formar

\footnotetext{
62 HABERMAS, Jürgen. Direito e Democracia: entre facticidade e validade. Vol. II, Rio de Janeiro: Tempo Brasileiro, 1997.

${ }^{63}$ HABERMAS, Jürgen. Direito e Democracia: entre facticidade e validade. Vol. II, Rio de Janeiro: Tempo Brasileiro, 1997, p.24.

${ }^{64}$ HABERMAS, Jürgen. Direito e Democracia: entre facticidade e validade. Vol. II, Rio de Janeiro: Tempo Brasileiro, 1997, p.23.

65 HABERMAS, Jürgen. Direito e Democracia: entre facticidade e validade. Vol. II, Rio de Janeiro: Tempo Brasileiro, 1997, p.22.
} 
AMARAL, Jordana Siteneski do; MACHADO, Deborah da Silva. Mídia, monopólio e democracia: um estudo sobre a monopolização da mídia no Brasil e porque isso pode ser uma ameaça à democracia. Revista Eletrônica Direito e Política, Programa de Pós-Graduação Stricto Sensu em Ciência Jurídica da UNIVALI, Itajaí, v.13, n.2, $2^{\circ}$ quadrimestre de 2018. Disponível em: www.univali.br/direitoepolitica - ISSN 1980-7791

uma opinião pública e canalizar as demandas da sociedade para que estas sejam normatizadas e regulamentadas pelo Estado.

Neste aspecto, reitera-se a importância assumida pela esfera pública para a caracterização de uma democracia nestes moldes, pois é dentro dela e através dela que os fluxos de comunicação pulsam após serem filtrados e sintetizados, e posterirormente transformam-se em opinião pública66.

Ao falar de esfera pública e suas prerrogativas, Habermas atenta que o surgimento dos meios de comunicação de massa possibilitou que a mídia concentrasse capital, se organizasse em grandes grupos centralizados, e que tal fato ensejou o surgimento de outra forma de poder: o poder da mídia ${ }^{67}$. O problema dessa concentração, é que ela possibilitou a "despolitização" da esfera pública, já mencionada, transformando-a em espaço comercial para disputa de audiência e lotando-a com entretenimento. A ocorrência destes eventos, o autor atribui principalmente, ao fenômeno da Indústria Cultural. ${ }^{68}$ Afirma ainda, que uma alternativa para neutralizar este "poder da mídia", é exatamente a regulamentação ${ }^{69}$.

A concepção de democracia deliberativa de Habermas, como se viu, estreitamente ligada ao discurso, reconhece a importância da comunicação para a caracterização de um governo democrático, onde a sociedade pode efetivamente, participar da administração do Estado. A esfera pública, meio pelo qual os indivíduos podem "ter voz" constitui a principal forma de canalizar as demandas da sociedade.

Obteve grande adesão, durante um tempo significativo, a prática do "Orçamento Participativo", onde os cidadãos de diversas cidades reuniam-se em seus bairros para

66 HABERMAS, Jürgen. Direito e Democracia: entre facticidade e validade. Vol. II, Rio de Janeiro: Tempo Brasileiro, 1997, p.92.

67 HABERMAS, Jürgen. Direito e Democracia: entre facticidade e validade. Vol. II, Rio de Janeiro: Tempo Brasileiro, 1997, p.109-110.

${ }^{68}$ A teoria da Indústria Cultural deriva da escola Crítica de Frankfurt, e a criação do conceito foi formulada por Theodor Adorno e Max Horkheimer nos anos 1940. Esta teoria criticava como a industrialização da produção de bens culturais transformou a cultura em mercadoria, transformando-a em um bem de consumo que poderia ser vendido e barganhado. Tal fato, apesar de popularizar a arte a esvaziou de seu conteúdo, produzindo bens massificados e padronizados, desprovidos de particularidades. Seguindo a lógica da produção em série inaugurada pela Revolução Industrial, a indústria cultural banalizou a arte, retirou seu conteúdo crítico e reflexivo com o objetivo de auferir rentabilidade e controle social. In: MATTELART, Armand; MATTELARD, Michèle. História das teorias da comunicação. 1.ed. São Paulo: Loyola, 2000.

69 HABERMAS, Jürgen. Direito e Democracia: entre facticidade e validade. Vol. II, Rio de Janeiro: Tempo Brasileiro, 1997, p.112. 
AMARAL, Jordana Siteneski do; MACHADO, Deborah da Silva. Mídia, monopólio e democracia: um estudo sobre a monopolização da mídia no Brasil e porque isso pode ser uma ameaça à democracia. Revista Eletrônica Direito e Política, Programa de Pós-Graduação Stricto Sensu em Ciência Jurídica da UNIVALI, Itajaí, v.13, n.2, $2^{\circ}$ quadrimestre de 2018. Disponível em: www.univali.br/direitoepolitica - ISSN 1980-7791

deliberar quais investimentos e obras deveriam ser realizados em suas comunidades. $\mathrm{O}$ instrumento, baseado na teoria habermasiana, tornou-se parte do discurso político que propunha "maior e melhor" participação da cidadania nas decisões do município. ${ }^{70}$

Também, a mídia apresenta-se como uma potencial ferramenta de accountability na sociedade, garantindo transparência na gestão pública e na prestação de contas à sociedade, reduzindo os índices de corrupção, e consequentemente, reafirmando os valores democráticos. A imprensa livre é provavelmente a instituição mais eficaz para controlar a corrupção, pois estando independente, os jornalistas conseguem investigar qualquer irregularidade. ${ }^{71}$

\subsection{LIBERDADE DE IMPRENSA E LIBERDADE DE EXPRESSÃO}

Romper com a situação já consolidada de oligopólio midiático no Brasil não é tarefa fácil, mesmo que a sociedade assim queira e entenda a importância de tal movimento, existem diversos óbices no caminho para a democratização da comunicação. A própria grande mídia com receio de perder sua hegemonia não poupa esforços para impedir que comunicação se torne plural, promovendo verdadeiras campanhas a fim de escamotear o problema e convencer a população de que uma regulamentação seria inclusive, "antidemocrática".

Um dos principais argumentos utilizados para rebater a necessidade de uma regulamentação das mídias é a de que esta regulamentação e a intervenção estatal causaria um embaraço à liberdade de imprensa. Esse argumento é, na maioria das vezes, utilizado de forma inadequada nos discursos midiáticos, com a nítida intenção de causar confusão na sociedade. Os grandes conglomerados de mídia se agarram à expressão liberdade de imprensa, e a confundem, propositadamente, com liberdade de

\footnotetext{
70 Para entender os mecanismos e a amplitude, além de um balanço crítico, ver: "O Orçamento Participativo e a teoria democrática: um balanço crítico". AVRITZER, Leonardo. Disponível em: http://www.plataformademocratica.org/Publicacoes/Publicacao_10929_em_21_06_2011_15_48_32.pdf Acessado em: 23 de agosto de 2016.

71 BRUNETTIA, Aymo; WEDERB, Beatrice. A free press is bad news for corruption. Journal of Public Economics, 87, pgs.1801-1824, Elselvier, 2003.
} 
AMARAL, Jordana Siteneski do; MACHADO, Deborah da Silva. Mídia, monopólio e democracia: um estudo sobre a monopolização da mídia no Brasil e porque isso pode ser uma ameaça à democracia. Revista Eletrônica Direito e Política, Programa de Pós-Graduação Stricto Sensu em Ciência Jurídica da UNIVALI, Itajaí, v.13, n.2, 20 quadrimestre de 2018. Disponível em: www.univali.br/direitoepolitica - ISSN 1980-7791

expressão, referindo-se ao tema como se fossem a mesma coisa e correspondessem a mesma realidade ${ }^{72}$.

No entanto, não se deve, nem pode confundir liberdade de imprensa, com liberdade de expressão. Cada uma dessas expressões tem suas particularidades, e surgem em determinados contextos e realidades sociais, históricas e políticas diferentes, para salvaguardar um direito diferente.

Liberdade de imprensa significa "liberdade de imprimir"73. Quando Gutemberg aperfeiçoou a prensa de tipos móveis, por volta de 1450, um novo cenário na comunicação foi inaugurado. A facilidade da reprodução em larga escala dos bens simbólicos (textos, discursos, ideias, livros) que o meio técnico proporcionou, teve profundos impactos sociais, uma vez que a impressão representou uma mudança nos centros e redes de poder simbólico (a força do discurso, por exemplo) que muitas vezes escapavam ao controle do Estado Moderno e da Igreja. Essa 'revolução' representou para as instituições da época, uma ameaça ao poder, uma fragmentação da autoridade religiosa e política, de forma que tanto a Igreja quanto o Estado passaram a utilizá-la em beneficio próprio e posteriormente, restringir seu uso ${ }^{74}$. Neste contexto, o cerceamento da liberdade de imprimir significava o controle da imprensa, e consequentemente, das ideias difundidas e veiculadas.

Contudo, é preciso ter em mente que hoje, os atores da imprensa modificaram-se: não são mais os pequenos grupos revolucionários que imprimiam panfletos independentes que enfrentavam a represália de governos autocráticos. A mídia hoje é estruturada em torno de imponentes impérios e empresas com faturamentos astronômicos ${ }^{75}$.

72 LIMA, Venício A. de. Liberdade de expressão $\mathbf{x}$ Liberdade da imprensa: direito à comunicação e democracia. São Paulo: Publihser, 2 ed., 2012.

73 GUARESCHI, Pedrinho A. O direito humano a comunicação: pela democratização da mídia. Rio de Janeiro: Vozes, 2013, p.96.

74 THOMPSON, Jonh B.. A mídia e a modernidade: uma teoria social da mídia. 7a Edição, Petrópolis, RJ: Vozes, 2005, p.54-58.

75 GUARESCHI, Pedrinho A. O direito humano a comunicação: pela democratização da mídia. Rio de Janeiro: Vozes, 2013, p.96. 
AMARAL, Jordana Siteneski do; MACHADO, Deborah da Silva. Mídia, monopólio e democracia: um estudo sobre a monopolização da mídia no Brasil e porque isso pode ser uma ameaça à democracia. Revista Eletrônica Direito e Política, Programa de Pós-Graduação Stricto Sensu em Ciência Jurídica da UNIVALI, Itajaí, v.13, n.2, $2^{\circ}$ quadrimestre de 2018. Disponível em: www.univali.br/direitoepolitica - ISSN 1980-7791

A liberdade de expressão por sua vez, constitui o âmago do direito humano à comunicação. Ele refere-se à liberdade que cada sujeito tem de expressar-se livremente, através de diferentes meios, suas opiniões, valores e crenças ${ }^{76}$.

No entanto, liberdade de imprensa e liberdade de expressão não devem ser excludentes. Ao contrário, elas se retroalimentam na medida em que a liberdade de imprensa deve servir para viabilizar a liberdade de expressão. Atualmente, porém, a liberdade de imprensa deve ser interpretada com cautela, observando o contexto onde surgiu - onde a imprensa uma forma de contra poder e resistência, por exemplo - sob pena de estar-se defendendo os interesses das grandes empresas de mídias, sob uma ideia de liberdade de imprensa que foi descontextualizada.

Falar somente em liberdade de imprensa sem as devidas considerações implicaria em atribuir uma personalidade à "imprensa". Nesse diapasão, Guareschi argumenta que a "imprensa" em si não existe, razão pela qual não seria titular de um direito à liberdade de expressão. O que existe segundo ele, é uma pessoa que se expressa e se comunica por meio da imprensa, isto é, das mídias impressa ou imagética. E a essa liberdade dáse outro nome: liberdade de expressão, não liberdade de imprensa. A imprensa pode ser o órgão ou empresa que imprime, ou ainda uma instituição. De qualquer forma a imprensa, não é um ser dotado de personalidade e consciência, a não ser por seus "donos"77.

Há que se convir então, que a expressão "liberdade de imprensa" se presta perfeitamente ao discurso das grandes empresas de comunicação, jornais e revistas incluídos, atrás do qual se escondem para dizer qualquer coisa, sobre qualquer pessoa que queiram diminuir ou elevar.

\subsection{REGULAMENTAÇÃO OU CENSURA?}

Outro argumento utilizado, na tentativa de impedir uma regulação da mídia - e, consequentemente, a democratização de seus espaços e discursos - é o raciocínio de que uma regulamentação seria uma forma de censura.

\footnotetext{
${ }^{76}$ GUARESCHI, Pedrinho A. O direito humano a comunicação: pela democratização da mídia. Rio de Janeiro: Vozes, 2013, p.96.

77 GUARESCHI, Pedrinho A. O direito humano a comunicação: pela democratização da mídia. Rio de Janeiro: Vozes, 2013, p.96.
} 
AMARAL, Jordana Siteneski do; MACHADO, Deborah da Silva. Mídia, monopólio e democracia: um estudo sobre a monopolização da mídia no Brasil e porque isso pode ser uma ameaça à democracia. Revista Eletrônica Direito e Política, Programa de Pós-Graduação Stricto Sensu em Ciência Jurídica da UNIVALI, Itajaí, v.13, n.2, $2^{\circ}$ quadrimestre de 2018. Disponível em: www.univali.br/direitoepolitica - ISSN 1980-7791

De acordo com Bello e Ribeiro o Brasil vive uma realidade excludente em termos de comunicação, e não há dúvidas de que essa exclusão é uma violação à Constituição em nível de princípios e de garantias de acesso à informação e a regulação dos meios de comunicação social78:

Nas condições de um oligopólio plutocrático, o mesmo discurso ideológico se produz e se reproduz, tornando-se o meio mais poderoso de resistência reacionária as mudanças democráticas constitucionais. Apelando-se inclusive para interpretações distorcidas de valores democráticos, difunde-se a ideia de que qualquer regulação dos meios de comunicação é uma forma de censura. ${ }^{79}$

O motivo da existência da censura como política de Estado é bastante claro e poderia se resumir, basicamente, a controle social e manutenção do poder. Em linhas gerais, a censura em sua forma tradicional caracteriza-se por ser uma "proibição explícita e prévia da divulgação de determinado conteúdo", através de ordens expressas, ou até mesmo em casos mais extremos, de coação física dos censores ${ }^{80}$. Embora esta seja a forma mais conhecida de censura, ela não é a única. Existem outras que compreendem aspectos mais complexos do que a coerção, apreensão ou a proibição de veicular alguns temas ou opiniões.

Essa forma de censura ocorreu especialmente no país nos períodos ditatoriais da década de 1930 e em 1967 e quando houve a perseguição a órgãos de imprensa que ousavam insurgirem-se, e o cerceamento da liberdade de expressão teve seu ápice com os Atos Institucionais números 5 e 12, além da Lei de Segurança Nacionalo1.

Como esse artigo trata do monopólio da comunicação, garantida por oligopólio, ambos definidos e justificados no início, não se pode falar em liberdade de expressão e

78 BELLO, Enzo; RIBEIRO, Samantha S. Moura (orgs.). Os meios de comunicação no Brasil atual: entre a normatividade democrática da Constituição e a Realpolitk da mídia oligárquica. In: BELLO, Enzo; RIBEIRO, Samantha S. Moura (orgs.). Democracia nos meios de comunicação: Pluralismo, Liberdade de Expressão e Informação. Rio de Janeiro, Lumen Juris, 2016, p.6.

79 BELLO, Enzo; RIBEIRO, Samantha S. Moura (orgs.). Os meios de comunicação no Brasil atual: entre a normatividade democrática da Constituição e a Realpolitk da mídia oligárquica. In: BELLO, Enzo; RIBEIRO, Samantha S. Moura (orgs.). Democracia nos meios de comunicação: Pluralismo, Liberdade de Expressão e Informação. Rio de Janeiro, Lumen Juris, 2016, p.6.

80 PIERANTI, Octavio Penna. Censura versus Regulação de Conteúdo. In: SARAIVA, Enrique; MARTINS, Paulo Emílio Matos; PIERANTI, Octavio Penna (Orgs.) Democracia e regulação dos meios de comunicação de massa. In: Rio de Janeiro: Editora FGV, 2008,

${ }^{81}$ CARdoso, Monteiro A.; CARVAlHo, Alberto A. de. A liberdade de imprensa. Lisboa: Editora Meridiano, 1967, p.201. 
AMARAL, Jordana Siteneski do; MACHADO, Deborah da Silva. Mídia, monopólio e democracia: um estudo sobre a monopolização da mídia no Brasil e porque isso pode ser uma ameaça à democracia. Revista Eletrônica Direito e Política, Programa de Pós-Graduação Stricto Sensu em Ciência Jurídica da UNIVALI, Itajaí, v.13, n.2, $2^{\circ}$ quadrimestre de 2018. Disponível em: www.univali.br/direitoepolitica - ISSN 1980-7791

imprensa livre se a mídia se organiza em gigantes conglomerados que detêm o poder de veicular o conteúdo e forma de apresenta-lo da forma que entenderem, com voz uníssona, questiona-se: o fato de poucos grupos (oligopólio) deterem o poder de comunicar (uma única ideia) já não seri uma forma de censura?

Para Ramonet a censura também existe em sociedades ditas "democráticas". Essa forma de censura funciona baseada em outros critérios que não o da violência: comerciais e econômicos. Não é proibindo os jornais, ou ocultando e suprimindo informações que a censura ocorre majoritariamente hoje. A informação não é mais controlada com base na sua circulação, mas na sua dissimulação e supressão82.

A censura também pode ser econômica, quando se aproveita da situação financeira precária de alguns veículos, o governo concede incentivos e financiamento a juros baixos para capitalizar empresas de comunicação e mais, faz publicidade oficial para aquele veículo favorável às suas políticas ${ }^{83}$.

Logo, a censura hoje ocorre de uma forma velada, silenciosa. Ela ocorre quando os discursos dissonantes são abafados, quando a pluralidade, que é essencial à democracia é frustrada, e quando poucos têm a prerrogativa de se expressar. Esse é o caso das sociedades, como o Brasil, cuja mídia se organiza lenta e paulatinamente, em direção a um só discurso, a fim de manter o status quo.

\section{CONSIDERAÇÕES FINAIS}

A comunicação desempenha um papel fundamental em uma democracia, partindo de uma concepção baseada na participação e na soberania popular, uma vez que constitui importante ferramenta de accountability e de participação deliberativa, na medida em que possibilita que a coletividade entre em consenso sobre as suas demandas a fim de vê-las regulamentadas pelo Estado. Não obstante, a liberdade de expressão é condição para o exercício de uma série de direitos que dela decorrem, como as liberdades de opinião e de acesso à informação, bem como como os próprios direitos políticos de escolher representantes e de deliberar sobre a vida na sociedade. Por derradeiro, ela é

${ }^{82}$ RAMONET, Ignacio. A tirania da comunicação. 4a edição, Petrópolis, RJ: Vozes, 2007, p.45.

83 PIERANTI, Octavio Penna. Censura versus Regulação de Conteúdo. In: SARAIVA, Enrique; MARTINS, Paulo Emílio Matos; PIERANTI, Octavio Penna (Orgs.) Democracia e regulação dos meios de comunicação de massa. In: Rio de Janeiro: Editora FGV, 2008, p.136. 
AMARAL, Jordana Siteneski do; MACHADO, Deborah da Silva. Mídia, monopólio e democracia: um estudo sobre a monopolização da mídia no Brasil e porque isso pode ser uma ameaça à democracia. Revista Eletrônica Direito e Política, Programa de Pós-Graduação Stricto Sensu em Ciência Jurídica da UNIVALI, Itajaí, v.13, n.2, $2^{\circ}$ quadrimestre de 2018. Disponível em: www.univali.br/direitoepolitica - ISSN 1980-7791

um direito fim e um direito meio, sendo um dos pilares que sustentam um regime verdadeiramente democrático.

Mas a comunicação hoje é por excelência, mediada por meios técnicos. Razão pela qual, para que se fale em exercício pleno do direito à liberdade de expressão e dos direitos que dele decorrem, é necessário que se assegure a sociedade o amplo acesso e participação nesses meios técnicos de produção e divulgação de mensagens. Ou seja, necessariamente há que se falar na democratização do acesso aos meios de comunicação de massa. E com "democratizar o acesso", está se falando em proporcionar um fluxo de informação de duas vias, que pressupõe dialogicidade, participação de todas as instâncias da sociedade civil, propiciar que novos veículos de comunicação com propostas diferenciadas possam emergir e sustentar-se. Também se fala em abrir espaço para as diversidades políticas, para o reconhecimento e valorização das especificidades sociais e culturais de cada região, bem como utilizar os meios de comunicação e seu potencial para difusão do conhecimento.

Contudo, como ficou demonstrado, principalmente ao longo do primeiro capítulo, este não é o caso da comunicação no Brasil, onde meia dúzia de grupos privados dominam o cenário das comunicações, e por meio da propriedade cruzada, essas mesmas empresas dominam meios impressos e eletrônicos, portais de internet e operadoras de telefonia.

Em verdade, a formação de grandes conglomerados de mídias é uma característica da comunicação em âmbito global e decorre de uma confluência de eventos: a globalização, a emergência de novas tecnologias de informação, e a ausência de regulamentação por parte dos Estados, devido à adoção de uma política neoliberalista. Por tais razões, o processo de transformação da imprensa em mega indústrias de mídia iniciado ainda no século XIX, vem apenas se agravando, devido à conivência e permissividade de várias nações.

No caso pátrio, a concentração midiática ocorreu gradativamente, e teve como plano de fundo um contexto social e histórico peculiar, pois que a hegemonia da mídia começou ainda no início da exploração radiofônica e televisiva pela esfera privada e se intensificou na ditadura militar de 1964. Mas é no período de redemocratização que ela se consolida e expande seu poder, com o surgimento dos "coronéis eletrônicos" e do uso das concessões como forma de barganha no Congresso Nacional. 
AMARAL, Jordana Siteneski do; MACHADO, Deborah da Silva. Mídia, monopólio e democracia: um estudo sobre a monopolização da mídia no Brasil e porque isso pode ser uma ameaça à democracia. Revista Eletrônica Direito e Política, Programa de Pós-Graduação Stricto Sensu em Ciência Jurídica da UNIVALI, Itajaí, v.13, n.2, 20 quadrimestre de 2018. Disponível em: www.univali.br/direitoepolitica - ISSN 1980-7791

A formação de oligopólios na comunicação é prejudicial a qualquer sociedade democrática por uma série de razões. A primeira delas refere-se à pluralidade de informações e discursos como direito de cada pessoa e condição básica da democracia: o oligopólio proporciona os meios para a difusão de um único discurso, monopolizando a opinião pública, transmitindo uma única mensagem, ao mesmo tempo em que silenciam, pela omissão, as vozes dissonantes, ou contrárias.

Além de impossibilitar a pluralidade, os oligopólios permitiram (principalmente no caso brasileiro) a associação do poder midiático com o poder político, na medida em que a omissão do poder público abriu brechas legais para que membros do poder executivo e do legislativo obtivessem outorgas e concessões de veículos de comunicação.

Também, os meios de comunicação de massa ao praticamente substituírem as relações comunicativas de interação face a face, deslocaram para si a ideia de arena e fórum dos debates. Não seria exagero então, afirmar que hodiernamente eles constituem e formam a esfera pública. Se é na esfera pública que os sujeitos exercem seus direitos políticos, resta admitir que diante de uma mídia politicamente comprometida e conservadora, este direito está sendo prejudicado. Diante disso, chega-se a outra constatação: a pluralidade é essencial à democracia, e ela fica obstada, sem que se assegure o amplo acesso da sociedade às informações, à produção e à divulgação de bens simbólicos.

Democratizar o mass media, como tem sido demonstrado, não é tarefa fácil. Sobretudo, porque há uma atuação forte de setores da sociedade contra qualquer iniciativa de regulamentação. A oligopolização criou um empecilho ao debate público - o monopólio do discurso - na medida em que, a fim de escamotear a inexistência de uma mídia democrática, acusa-qualquer proposta de "autoritária", cerceadora da liberdade de imprensa e antidemocrática.

Ao defender cegamente a liberdade de imprensa, deturpa a consciência de que essa liberdade tão cara e amada está baseada no direito à liberdade de expressão, porque é o sujeito que se expressa através da mídia, ou da imprensa. A mídia é tão somente o meio técnico que medeia e difunde a mensagem que está sendo expressada. Logo, o argumento de que um marco regulatório para as comunicações seria uma forma de censura, não se sustenta, uma vez que os poucos veículos que fogem do discurso dominante amargam cerceamento, pois como visto, a censura vai muito além da coerção direta e física. 
AMARAL, Jordana Siteneski do; MACHADO, Deborah da Silva. Mídia, monopólio e democracia: um estudo sobre a monopolização da mídia no Brasil e porque isso pode ser uma ameaça à democracia. Revista Eletrônica Direito e Política, Programa de Pós-Graduação Stricto Sensu em Ciência Jurídica da UNIVALI, Itajaí, v.13, n.2, $2^{\circ}$ quadrimestre de 2018. Disponível em: www.univali.br/direitoepolitica - ISSN 1980-7791

Em que pese a desregulamentação não seja o único fator do qual decorrem os oligopólios, ela foi fator determinante. A Constituição vetou expressamente a formação de monopólios e oligopólios, proibiu que políticos obtivessem outorgas e concessões, assegurou direitos fundamentais, como a liberdade de expressão e opinião, e estabeleceu diretrizes para o funcionamento dos meios de comunicação. Mas, praticamente inexistem normas infraconstitucionais regulamentadoras, o que não lhes dá eficácia prática alguma. Os poucos instrumentos normativos existentes estão obsoletos e são facilmente burlados.

O que fazer então para tornar a comunicação mais democrática? De fato, não existe uma solução simples para o problema, que provém de uma trajetória histórica. Mas ao que tudo indica, a regulamentação representa ponto de partida para o processo de democratização da comunicação. Paralelamente, encontram-se também como alternativas a conscientização da população sobre seus direitos, o incentivo aos veículos de comunicação alternativos, e o fortalecimento do sistema de mídias público e estatal a fim de promover a pluralidade e a diversidade frente à hegemonia das grandes indústrias de mídia.

De tudo aqui escrito e discutido a hipótese afirmativa foi corroborada, enquanto que a negativa, foi refutada. A regulamentação dos meios de comunicação não configura uma censura, uma vez que esta pode ocorrer exatamente pelo comprometimento da pluralidade nos espaços de fala e discurso. A regulamentação dos meios de comunicação é um mecanismo de efetivação da democracia, ao assegurar a liberdade de expressão.

Desde o julgamento da ADPF 130 em 2009, há uma lacuna legislativa no que toca as leis de imprensa. Fica reiterada a necessidade de um marco regulatório no campo da comunicação, a fim de dar aplicabilidade prática ao que está estabelecido na Constituição Federal. E, para finalizar, não pode existir democracia quando não há pluralidade de informação.

\section{REFERÊNCIAS DAS FONTES CITADAS}

AVRITZER, Leonardo. O Orçamento Participativo e a teoria democrática: um balanço crítico. Disponível em: http://www.plataformademocratica.org/Publicacoes/Publicacao_10929_em_21_06_20 11_15_48_32.pdf Acessado em: 23 de agosto de 2016. 
AMARAL, Jordana Siteneski do; MACHADO, Deborah da Silva. Mídia, monopólio e democracia: um estudo sobre a monopolização da mídia no Brasil e porque isso pode ser uma ameaça à democracia. Revista Eletrônica Direito e Política, Programa de Pós-Graduação Stricto Sensu em Ciência Jurídica da UNIVALI, Itajaí, v.13, n.2, $2^{\circ}$ quadrimestre de 2018. Disponível em: www.univali.br/direitoepolitica - ISSN 1980-7791

BAGNOLI, Vicente. Introdução ao Direito da Concorrência: Brasil, Mercosul, Globalização, ALCA. São Paulo, Editora Singular, 2005.

BANDEIRA, Luiza; CORRÊA, Alessandra; CARMO, Márcia; JARDIM Claudia. Como funciona a regulamentação da mídia em outros países? BBC Brasil Notícia. 2014, Disponível <http://www.bbc.com/portuguese/noticias/2014/12/141128_midia_paises_lab> Acesso em: 07 de setembro de 2015

BELLO, Enzo; RIBEIRO, Samantha S. Moura (orgs.). Os meios de comunicação no Brasil atual: entre a normatividade democrática da Constituição e a Realpolitk da mídia oligárquica. In: BELLO, Enzo; RIBEIRO, Samantha S. Moura (orgs.). Democracia nos meios de comunicação: Pluralismo, Liberdade de Expressão e Informação. Rio de Janeiro, Lumen Juris, 2016.

BRASIL. Constituição (1988). Constituição da República Federativa do Brasil. Brasília, DF: Senado 1988. Disponível em: <http://www.planalto.gov.br/ccivil_03/Constituicao/Constituicao.htm> Acesso em: 21 maio 2016.

BRASIL. Decreto de 24 de junho de 2016. Brasília, DF: Diário Oficial da União, 27 junho 2016. Disponível em: <http://www.planalto.gov.br/ccivil_03/_Ato20152018/2016/Dsn/Dsn14396.htm> Acesso em: 23 agosto 2016.

BRASIL. Decreto Lei n $^{\circ}$ 52.795, de 31 de outubro de 1963. Brasília: DF, Senado, 1963. Disponível em: < http://www.planalto.gov.br/ccivil_03/decreto/Antigos/D52795.htm> Acesso em: 22 maio 2016.

BRASIL. Decreto Lei no 236 de 28 de fevereiro de 1967. Brasília, DF: Congresso Nacional, 1967. Disponível em: < http://www.planalto.gov.br/ccivil_03/decretolei/Del0236.htm > Acesso em Acesso em: 21 maio 2016.

BRITTOS, Valério Cruza. COLLAR, Marcello Scmitz. Direito à comunicação e democratização no Brasil. In: SARAIVA, Enrique; MARTINS, Paulo Emílio Matos; In: PIERANTI, Octavio Penna (Orgs.) Democracia e regulação dos meios de comunicação de massa. In: Rio de Janeiro: Editora FGV, 2008, p.72.

BRUNETTIA, Aymo; WEDERB, Beatrice. A free press is bad news for corruption. Journal of Public Economics, 87, pgs.1801-1824. Elselvier, 2003.

CARDOSO, Monteiro A.; CARVALHO, Alberto A. de. A liberdade de imprensa. Lisboa: Editora Meridiano, 1967, p.201

EMPRESA BRASIL DE COMUNICAÇÕES. Histórico. Disponível em: <http://www.ebc.com.br/institucional/sobre-a-ebc/o-que-e-a-ebc/2012/09/historico> Acesso em: 23 de maio de 2018.

GUARESCHI, Pedrinho A.; BIZ, Osvaldo. Mídia e Democracia. Porto Alegre: 2005.

HABERMAS, Jürgen. Direito e Democracia: entre facticidade e validade. Vol. II, Rio de Janeiro: Tempo Brasileiro, 1997. 
AMARAL, Jordana Siteneski do; MACHADO, Deborah da Silva. Mídia, monopólio e democracia: um estudo sobre a monopolização da mídia no Brasil e porque isso pode ser uma ameaça à democracia. Revista Eletrônica Direito e Política, Programa de Pós-Graduação Stricto Sensu em Ciência Jurídica da UNIVALI, Itajaí, v.13, n.2, 20 quadrimestre de 2018. Disponível em: www.univali.br/direitoepolitica - ISSN 1980-7791

HABERMAS, Jürgen. Mudança estrutural da Esfera Pública: investigações quanto a uma categoria da sociedade burguesa. Tradução de Flávio R. Kothe. Rio de Janeiro: Tempo Brasileiro, 1984.

INTERVOZES. Ação elaborada por Intervozes e PSOL questiona no STF constitucionalidade do controle de emissoras de rádio e TV por políticos. Coletivo Brasil de Comunicação Social: 06 de dezembro de 2015. Acesso em: 23 agosto 2016. Disponível em: <http://intervozes.org.br/acao-elaborada-por-intervozes-e-psolquestiona-no-stf-constitucionalidade-do-controle-de-emissoras-por-politicos/ > Acesso em: 17 setembro 2016.

KLEIN, Otávio José. A notícia em rede: processos e práticas de produção da notícia em rede regional de televisão. Passo Fundo: Universidade de Passo Fundo, 2013.

LIMA, Venício A de; LOPES, Cristiano Aguiar. Coronelismo Eletrônico de novo tipo (1999-2004): as autorizações de emissoras como moeda de barganha política. São Paulo: Instituto para o Desenvolvimento do Jornalismo (Projor), 2007, p.4. Disponível em:

<http://www.observatoriodaimprensa.com.br/download/Coronelismo_eletronico_de_n ovo_tipo.pdf> Acesso em: 19 outubro 2015.

LIMA, Venício A. de. Liberdade de expressão x Liberdade da imprensa: direito à comunicação e democracia. São Paulo: Publihser, 2 ed., 2012.

LIMA, Venício A. de; RABELO, Bráulio Santos. Monopólio ou Oligopólio? Contribuição ao debate. In: LIMA, Venício A de. Cultura do Silêncio e democracia no Brasil: ensaios em defesa da liberdade de expressão Brasília: Unb Editora, 2015.

LIMA, Venícios A. de Lima. As "brechas" legais do coronelismo eletrônico. Revista Aurora, vol. 1, São Paulo: PUC/SP, 2007. Disponível em: <http://revistas.pucsp.br/index.php/aurora/article/viewFile/6344/4652> Acesso em: 21 maio 2016;

MARINONI, Bruno. Concentração dos meios de comunicação de massa e o desafio da democratização no país. Revista Análise, $\mathrm{n}^{0} 13$, Fundação FriedrichEbert-Stiffung (FES) Brasil, São Paulo: novembro, 2015, p.11. Disponível em: <http://intervozes.org.br/wp-content/uploads/2016/02/Projeto-FES-Artigoconcentracao-meio.pdf> Acesso em: 22 maio 2016.

MARTINS, Ana Luiza; DE LUCA, Tânia Regina. (Orgs.) História da Imprensa no Brasil. 2.ed.,1 $1^{\text {a }}$ reimpressão, São Paulo: Contexto, 2012.

MATTELART, Armand; MATTELARD, Michèle. História das teorias da comunicação. 1.ed. São Paulo: Loyola, 2000.

MCCHESNEY, Robert W. Mídia global, neoliberalismo e imperialismo. In: MORAES, Dênis de (org.). Por uma outra comunicação. $2^{a}$ ed., Rio de Janeiro: Record, 2004.

McCOMBS, Maxwell. A teoria da Agenda: mídia e opinião pública. Petrópolis, Rio de Janeiro: Vozes, 2009.

MICHEL TEMER VAI AO SUPREMO A FAVOR DA CONCESSÃO DE RÁDIO E TV A PARLAMENTARES. Notícia Conjur. Disponível em: <https://www.conjur.com.br/2016- 
AMARAL, Jordana Siteneski do; MACHADO, Deborah da Silva. Mídia, monopólio e democracia: um estudo sobre a monopolização da mídia no Brasil e porque isso pode ser uma ameaça à democracia. Revista Eletrônica Direito e Política, Programa de Pós-Graduação Stricto Sensu em Ciência Jurídica da UNIVALI, Itajaí, v.13, n.2, $2^{\circ}$ quadrimestre de 2018. Disponível em: www.univali.br/direitoepolitica - ISSN 1980-7791

nov-11/temer-stf-favor-concessao-radio-tv-politicos> Acesso em 27 de fevereiro de 2018.

MIELKE, Ana Cláudia. Órgãos reguladores dependentes: um caminho para equacionar direitos. In: VARJÃO, Suzana. Violações de direitos na mídia brasileira: um conjunto de reflexões sobre como coibir violações de direitos no campo da comunicação de massa. Brasília, DF: ANDI, 2015. Disponível em: <http://intervozes.org.br/wpcontent/uploads/2015/06/guia_violacoes_volumeii_web-1.pdf> Acesso em: 22 maio de 2016.

PIERANTI, Octavio Penna. Censura versus Regulação de Conteúdo. In: SARAIVA, Enrique; MARTINS, Paulo Emílio Matos; PIERANTI, Octavio Penna (Orgs.) In: Democracia e regulação dos meios de comunicação de massa..

RSF, Repórteres sem fronteiras. Grupo Globo. Disponível em <http://brazil.momrsf.org/br/proprietarios/empresas/detail/company/company/show/grupo-globo/> Acesso em 17 de maio de 2018.

RSF, Repórteres sem fronteiras. Media Ownserhip Monitor Brasil. Disponível em:< http://brazil.mom-rsf.org/br/> Acesso em 08 de maio de 2018.

SANTOS, Milton. Por uma outra globalização: do pensamento único à consciência universal. 6 ed. - Rio de Janeiro: Record, 2001.

SARLET, Ingo Wolfgang. Liberdade de expressão e biografias não autorizadas notas sobre a ADI4.815. CONJUR. 19/6/2015.

THOMPSON, Jonh B.. A mídia e a modernidade: uma teoria social da mídia. $7^{a}$ Edição, Petrópolis, RJ: Vozes, 2005.

Recebido em: 27/02/2018

Aprovado em: 17/05/2018 